\title{
BÉRES JÚLIA
}

\section{Elpusztult települések és névbokraik az egykori Polgár területén*}

1. Az egykor a hajdúvárosok közé tartozó Polgár a 20. század elejéig sokkal nagyobb területen helyezkedett el, mint ma. Számos külterületi lakott hellyel és tanyával rendelkezett, melyek idővel önállósultak, így Polgár területéből négy település alakult ki: Görbeháza, Újszentmargita, Újtikos és Folyás. Tanulmányomban Polgár és a belöle alakult települések közül a Görbeháza és Újszentmargita területén elhelyezkedő középkori falvakat és ezek neveinek továbbélését fogom bemutatni.

Görbeháza 1945-ben alakult Görbeházpuszta, Lipcseihát, Nagykapros községrészekből. ${ }^{1}$ Újszentmargita 1947-ben lett önálló település, a következő területekböl: Bödönhát, Csurgóhát, Egyház, Fástanya, Fövényeshát, Kerecse, Kiscserepes, Lopóhát, Margitaerdő, Nagybagota, Nagyszögtanya, Szandalik, Szentmargitapuszta, Tukaszilágy (lakatlan része). ${ }^{2}$ 1950-ben Polgártól idecsatolták Nagyszögpusztát, 1974-ben viszont Bagota és Fövenyeshát Görbeházához került. ${ }^{3}$

Az egyes települések viszonylag nagy területen fekszenek: Polgár $97,46 \mathrm{~km}^{2}$, Újszentmargita $96,22 \mathrm{~km}^{2}$, Görbeháza $80,2 \mathrm{~km}^{2}$, Folyás $53,92 \mathrm{~km}^{2}$, Újtikos 35,29 $\mathrm{km}^{2}$. Polgár területe tehát a 20. századig összesen több mint $300 \mathrm{~km}^{2}$ volt. Ezen a hatalmas területen a középkorban több kis falu feküdt. Vegyük szemügyre elsőként azokat, amelyek a mai Újszentmargita határán belül helyezkedtek el! Elötte azonban szükséges röviden kitérnünk az ún. helynévbokrosodás jelenségére mint sajátos helynévkeletkezési folyamatra.

\footnotetext{
*A publikáció az MTA-DE Magyar Nyelv-és Névtörténeti Kutatócsoport programja keretében jött létre.

${ }^{1}$ Magyarország helységnévtára 1967. Bp., 1967. 713. (a továbbiakban Hnt.)

${ }^{2}$ Hnt. 718 .

${ }^{3}$ GAZDAG ISTVÁN et al. szerk.: Magyarország történeti statisztikai helységnévtára 11. HajdúBihar megye. Bp., 1997. 49., 88.
} 


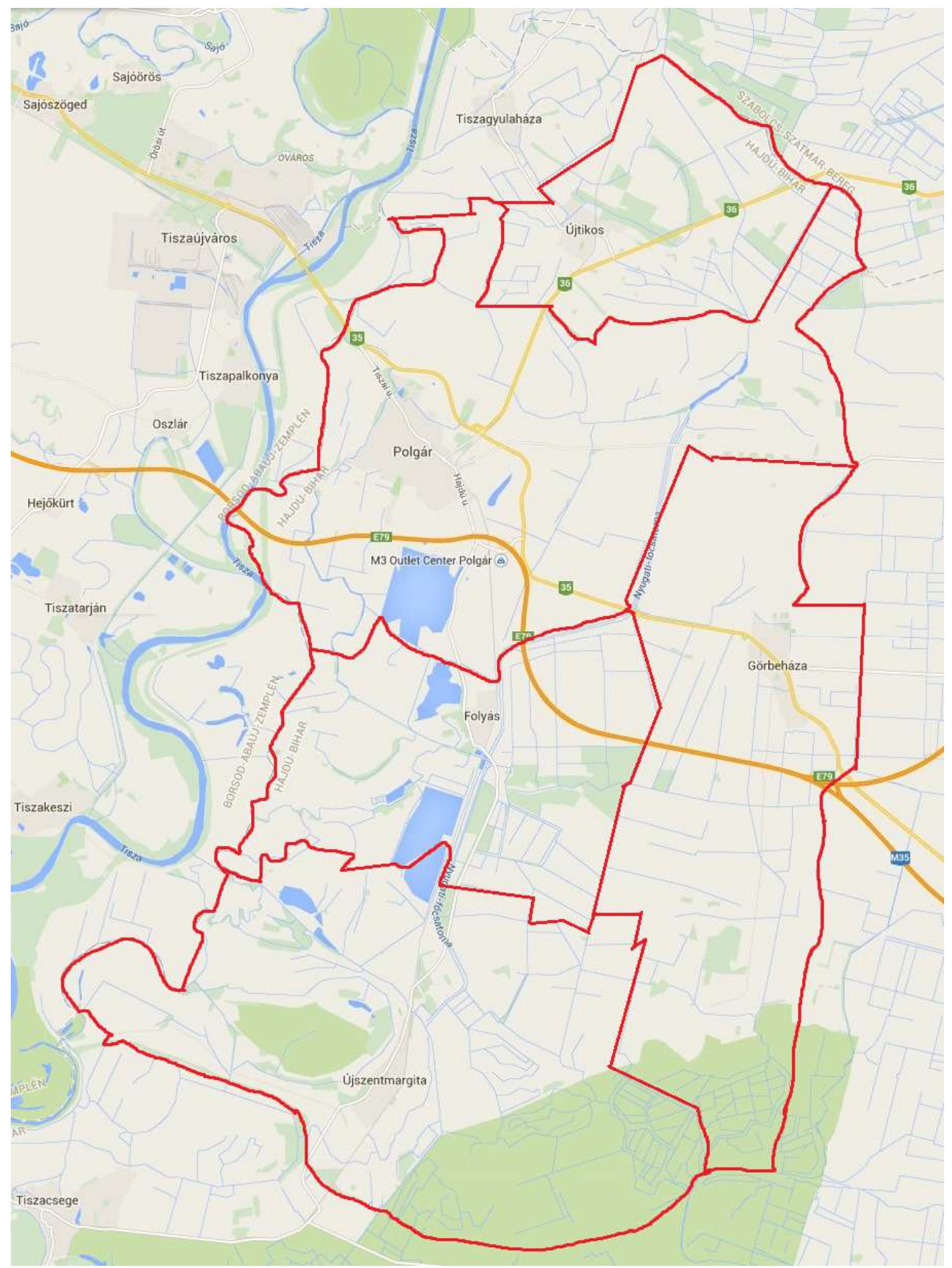

1. ábra: Polgár és a belőle alakult települések elhelyezkedése. 
2. A névbokrosodás olyan névkeletkezési folyamat, mely által valamely terület neve újabb helynevek névalkotójává válik. ${ }^{4}$ A jelenség eredményeként létrejöhetnek egyrészt az adott objektumot jelölő nevek szinonimái, másrészt a vele határos területek vagy az objektum területén belül elhelyezkedő egységek nevei is. ${ }^{5}$ Azokat a helyneveket, amelyekből újabb, más denotátumokat jelölő nevek keletkeztek, alapnév-nek, az alapnévből alakult neveket pedig másodlagos név-nek nevezzük. ${ }^{6} \mathrm{~A}$ helynévből alakult földrajzi nevek felszaporodása a magyar helynevekben általános volt az utóbbi évszázadokban. ${ }^{7}$ A magyar nyelv- és névtörténetnek a 13. századtól a 16. századig terjedő időszakában a víznevek és a településnevek felhasználásával keletkeztek leggyakrabban másodlagos helynevek ${ }^{8}$ - így van ez a vizsgált területen is, annál is inkább, hogy a középkorban átlagosan 4-5 falu is létezett egy-egy mai település határában. A legtöbb település a tatárjárás során pusztult el, sok nem is népesült újra. Maga a terület jellege sem kedvezett annak, hogy sürün lakott vidék maradjon Polgár és környéke: a Tisza áradásai után csaknem összefüggő vízállásos, mocsaras terület volt, kisebb hátságokkal, s csupán ezek voltak alkalmasak a megtelepülésre. ${ }^{9}$ Vízrajzilag is nagyon gazdag területről van szó, amelyet erek, tavak, nádasok, zsombékos rétek szabdaltak át.

A Polgár területén a 20. században önállósult falvak nagy névszükséglettel rendelkeztek: ebben elsősorban az játszhatott szerepet, hogy a Tisza szabályozása után jóval több terület vált megmunkálhatóvá, így a gazdálkodás szempontjából is fontossá vált, hogy az újabb megmüvelt területek is nevet kapjanak. Polgár hatalmas területén jó néhány külterületi lakott hely alakult a 19 . században, ${ }^{10}$ ezeket a külterületi lakott helyeket pedig a névközösség gyakran az ott létezett egykori falvakról nevezte el (mint például Tuka, Bagota esetében). De más típusú helyek megjelölésére is felhasználták a névkincsnek ezeket a régi, évszázados nyelvi múlttal rendelkező elemeit.

A már létező helynevek felhasználásával keletkező helynévbokrok sajátos típusát alkotják azok a helynevek, melyekben névalkotóként a magyar nyelvterületen fekvő középkori elpusztult települések nevei örzödtek meg. Az ilyen elpusztult települések nevéből keletkezett és határrész neveivé vált névcsaládok

\footnotetext{
${ }^{4}$ PÁSZTOR Éva: Elpusztult települések lokalizációjának kérdéséről. Helynévtörténeti Tanulmányok 5. Debrecen, 2010. 169-187.

${ }^{5}$ PÁSZTOR ÉVA: i. m., 172.

${ }^{6}$ KOCÁN BÉLA: A középmagyar kori Ugocsa vármegye helyneveinek névrendszertani vizsgálata. Helynévtörténeti Tanulmányok 3. Debrecen, 2008. 95-104.

${ }^{7}$ HOFFMANN ISTVÁN: A helynévrendszer változásai egy határrésszé vált településen. Magyar Nyelvjárások, (1984-85) 26-27. 103-114.

${ }^{8}$ Ehhez lásd KoCÁN BÉLA: i. m.

${ }^{9}$ MóDY GYÖRGY: Polgár és vidéke a tatárjárástól a hajdúk letelepedéséig. In: Polgár története. Szerk.: BENCSIK JÁNOS. Polgár, 1974. 41-86. 43-44.

${ }^{10}$ NYAKAS MiKLós: Görbeháza telepesközség létrejötte. Hajdúsági Múzeum Évkönyve 9. Szerk.: NYAKAS MiKLÓs. Hajdúböszörmény, 1999. 199-284.
} 
jórészt az elpusztult falvak birtokhatárán belül találhatók. ${ }^{11}$ Ez segíthet bennünket a települések lokalizálásában.

3. A mai Újszentmargita település nevét az egykor ezen a területen fekvő Fejérszentmargita faluról kapta, melynek első okleveles említése 1261/1271-ből való: Feierzenthmargita ... in $C-u$ de Zabouch: ${ }^{12}$ e dokumentumban Béla király megerősíti az egri egyházmegyét korábbi birtokadományaiban, jogaiban és kiváltságaiban. A nagy kiterjedésú birtokállományban az utolsó csoportban, a Szent István adományozta Szabolcs vármegyei ingatlanok között szerepel Fehérszentmargita halászaival és halászó vizeivel. ${ }^{13}$ Templomát Antiochiai Szent Margit tiszteletére szentelték, innen kapta nevét (helységneveink és templomaink patrónusaként időrendi és tisztelettörténeti megfontolások miatt ugyanis csak ő jöhet szóba). ${ }^{14}$ A régészeti kutatások adatai szerint e templom az egykori Koponyacsárdának helyet adó dombon fekhetett, a valamikori falu pedig körülötte terülhetett el. ${ }^{15}$ Az egykori Szentmargita (Fehérszentmargita) területén fekszik tehát a mai település belterülete. A falu 1440-50 körül pusztásodott el Polgárral együtt, majd a Hunyadiak népesítették be újra. ${ }^{16}$ 1549-ben az egri káptalan birtokolja, ekkor 76 portája van (Polgárnak csak 70). ${ }^{17}$ 1554-ben Polgár és Szentmargita a leggazdagabb nyugat-szabolcsi települések között szerepel. ${ }^{18}$ A település 1600 körül néptelenedett el újra, ${ }^{19}$ még a hajdúk betelepülése előtt benépesült, majd 1631-ben ismét puszta lett. ${ }^{20}$ Később is települtek erre a területre, majd újra elnéptelenedett.

Németh Péter Szabolcs vármegye történeti földrajzában Szentmargita mellett Bag vagy Bagszeg, Szandalik, Szentmiklós és Tuka falvakat lokalizálja a mai Újszentmargita területére. Az alábbiakban ezek névbokrait tekintem át, a Bag Bagszeg problémáját azonban Görbeháza alatt, a 3. pontban tárgyalom.

Szandalik település neve már igen korán adatolható, elsőnek a százdi alapítólevél említi: [1067 k.]/1267: Zondonek. ${ }^{21}$ Az oklevél egy Szandalikról Cégénybe vezető utat említ. A falu a tatárjáráskor pusztult el, ${ }^{22}$ később nem épült

\footnotetext{
${ }^{11}$ INCZEFI GÉZA: A földrajzi nevek differenciálódásáról. Magyar Nyelv, (1965) 61/75-80. 78-79. o.

${ }^{12}$ GYÖRFFY GYÖRGY: Diplomata Hungariae Antiquissima. Volumen I. Bp., 1992. (a továbbiakban DHA I.) 60.

${ }^{13}$ SUGÁR ISTVÁN: Adatok Polgár, Szentmargita, Csősz, Kékes és Szentmiklós történetéhez (1261-1717). Polgár története. Szerk.: BENCSIK JÁNOS. Polgár, 1974. 417-502. 424/1.

${ }^{14}$ KISS LAJOS: Földrajzi nevek etimológiai szótára I-II. Negyedik, bővített és javított kiadás. Bp., 1988. (a továbbiakban FNESz.) és lásd MEZŐ ANDRÁs: A templomcím a magyar helységnevekben. 11-15. század. Bp., 1996. 148-149.

${ }^{15}$ MÓDY GYÖRGY: i. m., 42.

${ }^{16}$ Uo. 58.

${ }^{17}$ Magyarország birtokviszonyai a 16. század közepén. Szerk.: MAKSAY FERENC. 2. k. Bp., 1990. 698., 700.

${ }^{18}$ MÓDY GYÖRGY: i. m., 84.

${ }^{19}$ SUGÁR ISTVÁN: i. m., 453/90a.

${ }^{20}$ MÓDY GYÖRGY: i. m., 86.

${ }^{21}$ DHA I: 184.

${ }^{22}$ NÉMETH PÉTER: A középkori Szabolcs megye települései. Nyíregyháza, 1997. (a továbbiakban NÉMETH a). Németh Péter a Debreceni Egyetem Magyar Nyelvtudományi
} 
újjá, de külterületi lakott hely - ehhez lásd még: 1947: Szandalik ${ }^{23}$ - őrizte nevét Újszentmargitán még 1985-ben is. ${ }^{24}$ A Szandalik név eredeztetése igen bizonytalan. Az elsődleges Szandanék változat talán puszta személynévből keletkezett magyar névadással, az alapjául szolgáló személynév a szláv nyelvekből magyarázható, vö. lengyel Sędnik családnév. A szláv személynév köznévi előzménye lehet egy 'bíró' jelentésủ szó, vö. szb.-hv. R. sûdnīk, illetve a 'faedénykészítő, fatálgyártó' jelentésủ foglalkozásnév, vö. óor. субъникъ. ${ }^{25}$ Számos Szandalik lexémát tartalmazó név ismert Újszentmargitán, az alábbiakban ezeket mutatom be.

Szandalik-ér 'Görbeháza felől érkező, az újszentmargitai külterület keleti részén észak-dél irányban haladva a délkeleti határban a Hortobágyba ömlö ér' é. n. [1502 után a 16. század közepe táján]: Zandalos Ere, ${ }^{26}$ 1782-1785: Szandolik, ${ }^{27}$ 1853: Szandalik ${ }^{28}$ 1858: Szandalek ér $\sim$ Nagy kanal, ${ }^{29}$ 1864: Szandali fok, ${ }^{30}$ 1869-1887: Szandalek ér, ${ }^{31}$ 1900: Szandalék ér, ${ }^{32}$ 1909: Szandalik, ${ }^{33}$ 1909: Bágyszandálik, ${ }^{34}$ 1916: Szandalik, ${ }^{35}$ 1916: Szandalik csatorna, ${ }^{36}$ 1918: Szandalek $e ́ r,{ }^{37}$ 1924: Szandalek ér ${ }^{38}$ 1943: Szandalik (föcsat.), ${ }^{39}$ 1945: Szandalik

Tanszékének rendelkezésére bocsátotta a korábban megjelent könyvének újabb, átdolgozott kéziratát, amit ezúton köszönünk neki. A továbbiakban ebből a kéziratból származó idézések NÉMETH b hivatkozással szerepelnek. NÉMETH b: Szandalik szócikk.

${ }^{23}$ Magyar Nemzeti Levéltár (a továbbiakban MNL) Hajdú-Bihar Megyei Levéltára (a továbbiakban HBML) HBML V. 629/b. Görbeháza nagyközség iratai. 1. d. 1010/1947.

${ }^{24}$ GAZDAG ISTVÁN et al. szerk.: i. m., 87.

${ }^{25}$ FNESZ. Szandalik

${ }^{26}$ SUGÁR ISTVÁN: i. m., 442/54. B.

${ }^{27}$ Az elsö katonai felmérés. A Magyar Királyság teljes területe 965 nagyfelbontású színes térképszelvényen. 1782-1785. DVD-ROM. Bp., 2004. (a továbbiakban EKFT)

${ }^{28}$ MNL Országos Levéltára (továbbiakban OL) Kataszteri térképek S 78 223. téka Polgár 001-023 Markt Polgár in Ungarn Szabolcser Comitat. 1853. (mol.arcanum.hu)

${ }^{29}$ A második katonai felmérés. A Magyar királyság és a Temesi bánság nagyfelbontású, színes térképei. 1819-1869. DVD-ROM. Bp., 2005. (a továbbiakban MKFT)

${ }^{30}$ MizSER LAJOS: Szabolcs megye Pesty Frigyes 1864. évi helynévtárában (a továbbiakban Pesty: i. m.). A Nyíregyházi Jósa András Múzeum évkönyve 42. Szerk.: NÉMETH PÉTER. Nyíregyháza, 2000. 227-372. 247.

${ }^{31}$ Harmadik katonai felmérés 1869-1887, a Magyar Szent Korona Országai 1: 25. 000. DVD-ROM. Bp., 2007. (a továbbiakban HKFT)

${ }^{32}$ MNL Szabolcs-Szatmár-Bereg Megyei Levéltára (a továbbiakban SzSzBML) T 525. Csege. Zona 15, Col. XXIV. (1900.) (archivportal.arcanum.hu/szabolcs)

${ }^{33}$ MNL HBML VI. 127/lll. M. Kir. Állami 12. Földmérési Felügyelőség iratai (a továbbiakban VI. 127/lll.). 4. k. Felvételi előrajzok, Polgár, 1909., 140, 147, 148. és PAPP LÁSZLÓ-VÉGH JóZSEF szerk.: Hajdú-Bihar megye földrajzi nevei 1. Polgári járás. Debrecen, 1970. (a továbbiakban PJFN) 26.

${ }^{34}$ PJFN 26.

${ }^{35}$ MNL HBML Szabolcs megyei Kataszteri Térképek (a továbbiakban SzmK) 39/51. Újszentmargita, 1916.

${ }^{36}$ Uo. SzmK 39/50. Újszentmargita, 1916.

${ }^{37}$ MNL SzSzBML T 150. Szabolcs megye közúti és kőbánya térképe, 1918. (archivportal.arcanum.hu/szabolcs) 
csatorna,${ }^{40}$ 1945: Szandalik, ${ }^{41}$ 1948: Szandalik ${ }^{42}$ 1965: Szandalik-csatorna ${ }^{43}$ 1970: Szandalik, ${ }^{44} 2013^{45}$ : Bágy-Szandalik Bágy-szandaliki-csatorna Szandalikér.

Bágy-Szandalik 'a külterület délkeleti részén, a Szandalik-ér mellett fekvő szikes legelő, kaszáló, puszta' 1909: Szandalik, ${ }^{46}$ 1916: Szandalik, $^{47}$ 1945: Szandalik, ${ }^{48}$ 1946: Északszandalik Szandalik, ${ }^{49}$ 1947: Szandalik, ${ }^{50}$ 1956: Szandalik, ${ }^{51}$ 1959: Szandalik, ${ }^{52}$ 1965: Szandalik, ${ }^{53}$ 1968: Szandalik, ${ }^{54}$ 2013: Szandalik Bágy-Szandalik.

Szandalik-halom 'a külterület délkeleti részén, a Szandaliktól délre, a Debreceni-tábla mellett fekvő legelö' 1782-1785: Szandolik halom, ${ }^{55}$ 1869: Szándalék halom, ${ }^{56}$ 1909: Szandalik halom, ${ }^{57}$ 1909: Szandalik-halom, ${ }^{58}$ 1916: Szandalik halom ${ }^{59}$ 1970: Szandalik-halom ${ }^{60}$ 2013: Szandalik-halom Szandalikdomb.

\footnotetext{
$\begin{array}{lllllll}{ }^{38} \mathrm{MNL} & \text { SzSzBML } & \mathrm{T} & 462 . & \text { Debrecen } & \text { katonai }\end{array}$ (archivportal.arcanum.hu/szabolcs)

${ }^{39}$ Uo. T 584. Polgár és környéke (ideiglenes kiadás), 1943. (archivportal.arcanum.hu/szabolcs)

${ }^{40}$ MNL HBML XVII. 552. 1. d. A polgári földigénylő bizottság iratai. Polgár község határában a 600/1945 M. E. rendelet alapján kiosztott ingatlanok vázrajza 1-30. (a továbbiakban MNL HBML XVII. 552. 1. d.)

${ }^{41}$ MNL HBML XVII. 552. 1. d.

${ }^{42}$ MNL HBML SzmK 40/1-13. Újszentmargita, 1948.

${ }^{43}$ PeTE Gizella: Újszentmargita földrajzi nevei. K 475, 1965. (kézirat, Debrecen) 6.

${ }^{44}$ PJFN 26.

${ }^{45}$ Ezen évszám után az általam elvégzett élőnyelvi gyüjtés adatait tüntetem fel.

${ }^{46}$ MNL HBML VI. 127/l1l. 4. k. 145, 146, 148, 150, 151, 152, 153. és uo. 7. k. Polgár. Birtokrészleti jegyzőkönyv. 1909. No. 6452-10827.

${ }^{47}$ MNL HBML SzmK 39/50, 56, 55, 49, 51, 53, 54, 34, 48.

${ }^{48}$ Uo. XVII. 552. 1. d.

${ }^{49}$ Uo. XVII. 552. 1. d.

${ }^{50}$ Uo. V. 680/b. 1. d. Újtikos Kisközség (Tiszagyulaháza-Újtikos Körjegyzőség) iratai. Sz. n.

${ }^{51}$ MNL HBML XXIII. 9/c. Hajdú-Bihar Megyei Tanács VB Mezőgazdasági Osztály Iratai. Földrendezési iratok. 32. d. Tiszagyulaháza, Újszentmargita. Nyári tagosítás, Újszentmargita, 1956.

${ }^{52}$ Uo. Tiszagyulaháza, Újszentmargita. Kimutatás, Újszentmargita elhelyezkedési vázlat 1959. évi földrendezéshez.

${ }^{53}$ Pete Gizella: i. m., 6., 7.

${ }^{54}$ Terge LaJos: Földrajzinév-adás Polgáron és közvetlen környékén. K 563, 1968. (kézirat, Debrecen) 94.

${ }^{55}$ EKFT.

${ }^{56}$ MNL HBML VI. 127/1ll. 2. k. Polgár. Határleírás, 1869, 1908.

${ }^{57}$ Uo. VI. 127/11l. 4. k. 153.

${ }^{58}$ PJFN 27.

${ }^{59}$ MNL HBML SzmK 39/56.

${ }^{60}$ PJFN 27.
} 
Szandalik-zug 'a külterület délkeleti részén a Szandalik-ér és a Hortobágyfolyó által körbevett terület' 1909: Szandalik zug, ${ }^{61}$ 1909: Szandalik-zug, ${ }^{62}$ 1916: Szandalikzug, ${ }^{63}$ 1945: Szandalik zug, ${ }^{64}$ 1970: Szandalik-zug, ${ }^{65}$ 2013: Szandalik-zug.

Szandalik-tanya 1. 'egykori tanya a Szandalik-partján, a Szandalik-halom mellett' 1869-1887: Szandalék tn., ${ }^{66} 1900:$ Szandalék tn., ${ }^{67}$ 1904: Szandalek tanya, ${ }^{68}$ 1918: Szandalek tn., ${ }^{62}$ 1924: Szandalek tn. ${ }^{70}$

Szandalik-tanya 2. 'egykori tanya a Szandalik-partján, a Szandalik-ér és a Hortobágy-folyó összefolyásától északra' 1869-1887: Szandalek tn., ${ }^{71}$ 1889: Szandalek t. ${ }^{72}$ 1897: Szandalek $t^{73}$ 1900: Szandalék tn. ${ }^{74}$ 1904: Szandalek t. ${ }^{75}$

Szandalik-tanya 3. 'egykori tanya a Szandalik-partján, a Szandalik-ér és a Hortobágy-folyó összefolyásánál' 1858: Szandalek tanya. ${ }^{76}$

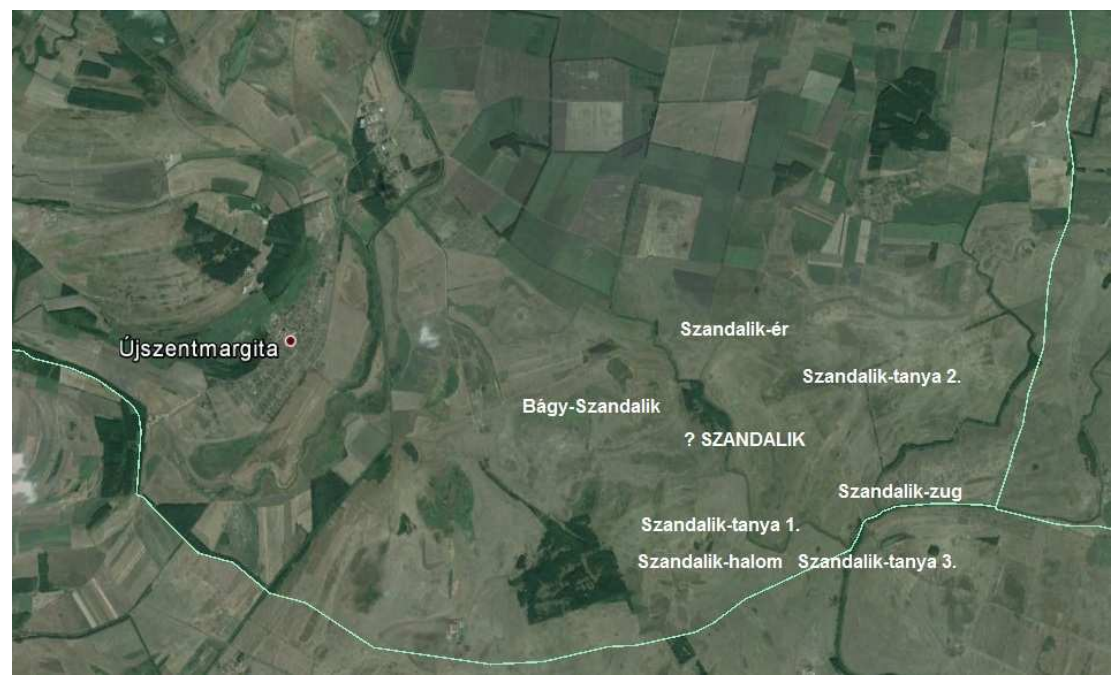

2. ábra: Szandalik névbokra.

\footnotetext{
${ }^{61}$ MNL HBML VI. 127/III. 4. k. 148.

${ }^{62}$ PJFN 27.

${ }^{63}$ MNL HBML SzmK 39/51.

${ }^{64}$ Uo. XVII. 552. 1. d.

${ }^{65}$ PJFN 27.

${ }^{66} \mathrm{HKFT}$.

${ }^{67} \mathrm{MNL}$ SzSzBML T 525.

${ }^{68}$ Kogutowicz Manó: Magyarország vármegyéinek kézi atlasza. Bp., 1904. 44.

${ }^{69}$ MNL SzSzBML T 150.

${ }^{70}$ Uo. T 462.

${ }^{71}$ HKFT.

${ }^{72}$ MNL SzSzBML T 108. Szabolcs megye térképe, 1889. (archivportal.arcanum.hu/szabolcs)

${ }^{73}$ Uo. T 373. Szabolcs vármegye térképe, 1897. (archivportal.arcanum.hu/szabolcs)

${ }^{74}$ Uo. T 525.

${ }^{75}$ Uo. T 110. Szabolcs vármegye és a Hajdú városok kerülete, 1802. (archivportal.arcanum.hu/szabolcs)

${ }^{76}$ MKFT.
} 
A következő egykori település a mai Újszentmargita területén Szentmiklós. Igen gazdagon adatolható a középkortól kezdve: 1352/1368: p. Zenmiclos, ${ }^{77}$ 1428: pr. Zenthmycklos, ${ }^{78}$ 1446/1446/1521: p. Zenthmyklos, ${ }^{79}$ 1459: Zenthmyklos p. ${ }^{80}$ 1460: p. Zenthmyklos, ${ }^{81}$ 1484: p. Zenthmyklos, ${ }^{82}$ 1484: Zenthmiklos, ${ }^{83}$ é. n. [1502 után a XVI. század közepe táján]: Zenthmyklos ${ }^{84}$ 1521: Zenth Myklos, ${ }^{85}$ 1521/1521: p. Zenthmyklos, ${ }^{86}$ 1521/1522: Zenthmyklos, ${ }^{87}$ 1661: Zenthmyklos, ${ }^{88}$ 1705: Szent Miklós, ${ }^{89}$ é. n. (1707 után): Szent Miklós Puszta, ${ }^{90}$ 1713: Szent Miklós, ${ }^{91}$ 1727: Szent Miklósi praedium, ${ }^{92}$ 1974: Szentmiklós. ${ }^{93}$

Csánki Dezső és Németh Péter Szentmiklós adatai alatt tárgyalja Csegeszentmiklós adatait is 1458: $p$. Chegezenthmyklos, ${ }^{94}$ 1460: $p$. Chegezenthmiklos, ${ }^{95}$ 1461: $p$. Chegezenthmyklos, ${ }^{96}$ 1464: p. Chegezenthmiklos, ${ }^{97}$ azonban a források alapján nem valószínü, hogy Szentmiklós és Csegeszentmiklós pontosan ugyanazon birtok neve lenne (Erről alább még lesz szó).

Nevét Szent Miklós tiszteletére szentelt egyházáról kapta. ${ }^{98}$ 1352-ben helységként tartották számon, később azonban többször elnéptelenedett. 1661-ben még helységként tartják számon, ekkor rendelik el határjárását, 1707 után viszont már puszta. ${ }^{99}$ Csánki Tiszacsege és Szentmargita puszta közé helyezi. ${ }^{100}$ A Tukai úttól délre húzódó hátságon talált régészeti leletek - köztük 10-11. századi Árpád-

\footnotetext{
${ }^{77}$ SUGÁR ISTVÁN: i. m., 427/5.

${ }^{78}$ A középkori Magyarország levéltári forrásai. (a továbbiakban DL; DF) CD-ROM. Bp., 2003. DL 54593.

${ }^{79}$ SUGÁR ISTVÁN: i. m., 428/8.

${ }^{80}$ NÉMETH b: Szentmiklós szócikk.

${ }^{81}$ DL 15491.

${ }^{82}$ DL 3766

${ }^{83}$ DL 19003.

${ }^{84}$ SUGÁR ISTVÁN: i. m., 442/54.C.

${ }^{85}$ Uo. 445/67.

${ }^{86}$ Uo. 445/65.

${ }^{87}$ Uo. 445/68.

${ }^{88}$ SUGÁR ISTVÁN: i. m., 457/103.

${ }^{89}$ Uo. 469/147.

${ }^{90}$ Uo. 469/148.

${ }^{91}$ Uo. 473/160.

${ }^{92}$ BenCSIK JÁNOS: A paraszti közösség gazdasági tevékenysége. Polgár története. Szerk.: BENCSIK JÁNOS. Polgár, 1974. 249.

${ }^{93}$ BENCSIK JÁNOS: i. m., 249.

${ }^{94}$ CSÁNKI DEZSÖ: Magyarország történelmi földrajza a Hunyadiak korában I. Bp., 1890. 526.

${ }^{95}$ NÉMETH b: Szentmiklós szócikk.

${ }^{96}$ Uo. Szentmiklós szócikk.

${ }^{97}$ Uo. Szentmiklós szócikk.

${ }^{98}$ MEZÖ ANDRÁs: i. m., 172.

${ }^{99}$ A település már a 16. században is pusztaként szerepel. SUGÁR ISTVÁN: i. m., 421.

${ }^{100}$ CSÁNKI DEZsÖ: i. m., 526.
} 
kori cserépanyagok - is segítséget nyújtanak a falu lokalizálásában. ${ }^{101}$ Balogh István 1952-ben keletkezett helyszíni jelentéséből kiderül, hogy a Morotva (ma: Tóicsatorna) keleti, meredek partján 13. századinak ítélt tégla és törmelékek kerültek elő. ${ }^{102}$ Sugár István szerint a meghatározás pontatlan, és valójában a Morotva nyugati partjának kelet felé fekvő meredekéről van szó, itt feküdt egy Árpád-kori falu szentegyháza. ${ }^{103} \mathrm{Az}$ egykori település minden bizonnyal e templom körül terülhetett el. Sugár maga az egykori falut a mai Szilágy, Tuka és Margita-erdő térségébe lokalizálja, holott Tuka a tatárjáráskor elpusztult Tuka falu nevét ỏrzi, így kezdetben idáig semmiképp nem terjedhetett Szentmiklós határa. Papp József szerint azonban egészen máshol kell keresni az egykori falu határát. Ö valószínúbbnek tartja, hogy a külterület déli részén, a nagyobb részben Tiszacsegéhez tartozó Cserepes környékén fekszik, mivel az előbbi elképzelés Újszentmargita déli részére lokalizálja a falut, ami szerinte túl közel fekszik az egykori Szentmargita faluhoz. ${ }^{104}$ M. Nepper Ibolya Cserepesen korabronzkori és szarmatakori leleteket talált. ${ }^{105}$ Ugyanakkor Szentmiklós egyházas falu lévén templommal kellett, hogy rendelkezzen. Mivel templomromot két helyen találtak: a Koponya-csárdánál (ami Szentmargita temploma lehetett), ${ }^{106}$ valamint az említett déli határrészen, úgy vélem Papp József elképzelése téves. Az élőnyelvi gyüjtés alkalmával az adatközlök is a határ déli részére, a csegei határ mellé lokalizálták Szentmiklós falvának elpusztult helyét (Fehérszentmiklósnak mondták, bizonyára analógiásan a Fehérszentmargita név mintájára). ${ }^{107}$ Noha 1727 után nem adatolható, de 1974-ben Bencsik szerint így neveznek egy puszta legelőt Szentmargitától délre. ${ }^{108}$ A Szentmargita és Csege közé való lokalizálást erősítik a Csegeszentmiklós nevek is, amelyek Szentmiklós Csege felé eső, vele határos részeit jelölhették meg önálló birtokként. 2013-ban az adatközlők nem ismerték határrész neveként. Több más elpusztult falu nevétől eltérően Szentmiklós neve tehát nem alkot határnévbokrot, sőt határrész sem őrzi nevét. Ennek okát leginkább azzal vélem magyarázhatónak, hogy az újabb korban, Szentmiklós határában külterületi lakott helyek nem létesültek.

\footnotetext{
${ }^{101}$ SugÁr IstVÁN: i. m., 421. és lásd még M. NePPER IbOLYA (a): Polgár és környéke a népvándorlás koráig. Polgár története. Szerk.: BENCSIK JáNOS. Polgár, 1974. 22.; M. NEPPER IBOLYA (b): A Polgári határ régészeti lelöhelyeinek katasztere. In: Polgár története. Szerk.: BENCSIK JÁNOS. Polgár, 1974. 416.

${ }^{102}$ MóDY GYÖRGY: Polgár és vidéke a tatárjárástól a hajdúk letelepedéséig. In: Polgár története. 43. és SUGÁR ISTVÁN: i. m., 421.

${ }^{103}$ SUGÁR ISTVÁN: i. m., 421.

${ }^{104}$ PAPP JÓZSEF: Tiszacsege. Hajdú-Bihar Megyei Múzeumok Közleményei 8. Debrecen, 1967. 29.

${ }^{105}$ M. NEPPER IBOLYA: A Polgári határ régészeti... 416.

${ }^{106}$ Uo. 416. és SUGÁr ISTVÁN: i. m., 420.

${ }^{107}$ Kevésbé valószínü, hogy ezt az ismeretet közvetlenül a kollektív emlékezet örizte meg, valószínübb lehet, hogy a helytörténeti munkák ismeretanyaga jelenik meg ilyen módon a helybeliek tudásában.

${ }^{108}$ BENCSIK JÁNOS: i. m., 249.
} 


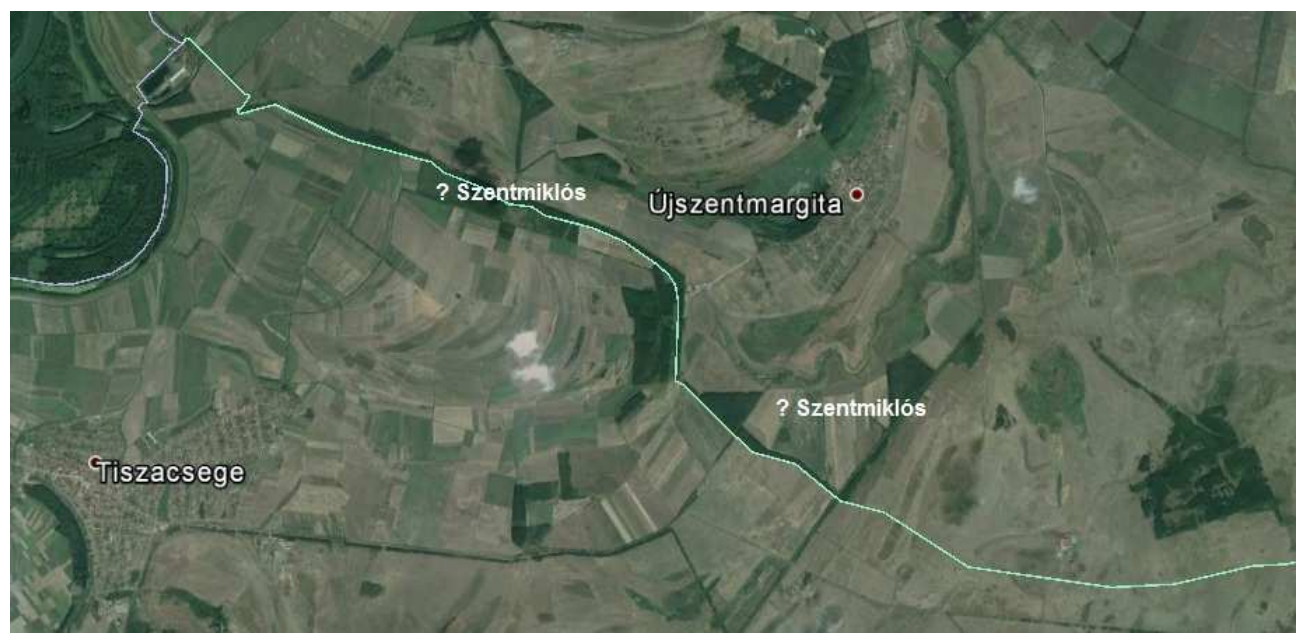

3. ábra: Szentmiklós feltételezett helyei.

Tuka 'Újszentmargita délnyugati határszögletében fekvő külterületi lakott hely' 1214/1550: Tuca, villa, ${ }^{109}$ 1900: Tuka, ${ }^{110}$ 1909: Tuka, ${ }^{111}$ 1916: Tuka, ${ }^{112}$ 1945: Tuka, ${ }^{113}$ 1947: Tuka, ${ }^{114}$ 1948: Tuka, ${ }^{115}$ 1956: Tuka, ${ }^{116}$ 1959: Tuka, ${ }^{117}$ 1965: Tuka, ${ }^{118}$ 1968: Tuka, -ba, ${ }^{119}$ 1970: Tuka, ${ }^{120}$ 1974: Tuka Margita-Tuka Tuka-Kisszilágy, ${ }^{121}$ 2013: Tuka. A település a tatárjáráskor elpusztult ${ }^{122}$, későbbi adatai nincsenek. Egykor az egri káptalan birtoka volt. 1868-tól újra lakott helyként jegyzik az egyházi anyakönyvek. ${ }^{123} \mathrm{Ma}$ is külterületi lakott hely Újszentmargitán, de mindössze néhányan laknak itt. A település neve valószínüleg személynévi eredetü,

${ }^{109}$ KARÁCSONYI JÁNOS-BOROVSZKY SAMU: Az időrendbe szedett Váradi tüzesvaspróbalajstrom az 1550-iki kiadás hü másával együtt. Bp., 1903. (a továbbiakban VR) 191.

${ }^{110}$ Magyarország vármegyéi és városai. Szabolcs vármegye. Szerk.: BoROVSZKY SAMU Bp., 1900. 71.

${ }^{111}$ MNL HBML VI. 127/l1l. 4. k. 104., 115-117, 125-127, 135., uo. 7. k. Birtokrészleti jegyzökönyv, 1909. No. 6452-10827. és PJFN 27.

${ }^{112}$ MNL HBML SzmK 39/38., 28., 29., 30., 7., 8., 19., 18., 20.

${ }^{113}$ Uo. XVII. 552. 1. d. Földigénylők összetevői íve; Polgári Földigénylő Bizottság iratai 1945.

${ }^{114}$ Uo. V. 629/b. 1. d.; uo. V. 680/b. 1. d.

${ }^{115}$ Uo. V. 663/b. 1. d. Polgár Nagyközség Iratai (a továbbiakban V. 663/b. 1. d.). Ad $1862 / 1948$.

${ }^{116}$ HBML XXIII. 9/c. 32. d.

${ }^{117}$ Uo. XXIII. 9/c. 32. d.

${ }^{118}$ PETE GiZELla: i. m., 9.

${ }^{119}$ TERGE LAJOS: i. m., 100.

${ }^{120}$ PJFN 27.

${ }^{121}$ BENCSIK JÁNOS: i. m., 251.

${ }^{122}$ NÉMETH b: Tuka szócikk.

${ }^{123}$ BENCSIK JÁNOS: i. m., 251. 
Polgáron 1715-ben adózók között is szerepel Stephanus Tuka. ${ }^{124}$ A tukai KisSzilágy, Király-tó, Szilfás-hát területeken is találtak szarmata és középkori régészeti leleteket is, ${ }^{125}$ így valószínüleg ezen a területen, a mai Tuka északi részén fekhetett a középkori falu.

Az alábbiakban a Tuka helynév névbokrát tekintem át.

Már meglévő területek megnevezésének előtaggal való bővülése:

Tuka(s)i-Gyürü-fok 'Tukától északra, a Selypes partján fekvő mélyfekvésü, belvizes szántóterület' 1782-1785: Gyuro Foka, ${ }^{126}$ 1853: Gyürüfok, ${ }^{127}$ 1864: gyürü foka, ${ }^{128}$ 1909: Gyürüfok, ${ }^{129}$ 1909: Gyürüfok, ${ }^{130}$ 1916: Gyürüfok, ${ }^{131}$ 1959: Gyürüfok, ${ }^{132}$ 1959: Gyürüfok, ${ }^{133}$ 1965: Gyürüfok, ${ }^{134}$ 1968: Gyürüfoka, -ba Gyürüfoki tábla, ra ${ }^{135}$ 1970: Gyürü foka Gyürü-fok Gyürü-foki-tábla, ${ }^{136}$ 1974: Gyürö fok Gyürü fok, ${ }^{137}$ 2013: Tukai-Gyürü-fok Tukasi-Gyürü-fok.

Tukai-legelő 'Tuka belterületétől délnyugatra a Tukai út és az Inta között fekvő legelö' 1858: Legelö, ${ }^{138}$ 2013: Tukai-legelö.

Tuka-Szilágy 'a külterület nyugati részén, a Tilos-erdőtől nyugatra fekvő fás, bokros, terület' 1782-84: Szilag, ${ }^{139}$ 1804-1808: Szilágy, ${ }^{140}$ 1808: Szilágy, ${ }^{141}$ 1853: Szilágy, ${ }^{142}$ 1864: Szilágyi, ${ }^{143}$ 1909: Tukaszilágy, ${ }^{144}$ 1934: Tukaszilágy, ${ }^{145}$ 1916:

\footnotetext{
${ }^{124}$ Urbáriumok és összeírások a Magyar Országos Levéltárban (Urbaria et conscriptiones). Szerk.: H. Németh István. CD-ROM. Bp., 2004.

${ }^{125}$ FÜZESI ANDRÁS: A neolitikus településszerkezet mikroregionális vizsgálata a Tisza mentén Polgár és Tiszacsege között. Tiscium - A Jász-Nagykun-Szolnok Megyei Múzeum Évkönyve 19. Szerk.: TÁRNOKI JUDIT. Szolnok, 2009. 387.

${ }^{126}$ EKFT.

${ }^{127}$ MNL OL S 78 223. téka Polgár 001-023.

${ }^{128}$ Pesty: i. m., 247.

${ }^{129}$ MNL HBML VI. 127/11l. 4. k. 116., 117.

${ }^{130}$ PJFN 27., és MNL HBML VI. 127/11l. 7. k.

${ }^{131}$ MNL HBML SzmK 39/19, 20.

${ }^{132}$ Uo. XXIII. 9/c. 32. d.

${ }^{133}$ Uo. XXIII. 9/c. 32. d.

${ }^{134}$ Pete GIZELLA: i. m., 7, 8.

${ }^{135}$ TERGE LAJOS: i. m. $98,99$.

${ }^{136}$ PJFN 27.

${ }^{137}$ BENCSIK JÁNOS: i. m. 236.

${ }^{138}$ MKFT.

${ }^{139}$ MNL OL Helytartótanácsi térképek S 12 Div XI No 0002 Geographische Charte des Königreichs Hungarn. 1782-84. (mol.arcanum.hu)

${ }^{140}$ LIPSZKY JÁNOS: Mappa generalis regni Hungariae. Pest, 1804-1808. In: LIPSZKY JÁNOS: A Magyar Királyság és társországai térképe és névtára (1804-1810). DVD-ROM. Bp., 2005. (a továbbiakban Lipszky: Mappa)

${ }^{141}$ LIPSZKY JÁNOS: Repertorium locorum. 1808. In: LIPSZKY JÁNOS: A Magyar Királyság és társországai térképe és névtára (1804-1810). DVD-ROM. Bp., 2005.

${ }^{142}$ MNL OL S 78 223. téka Polgár 001-023.

${ }^{143}$ Pesty: i. m., 247.

${ }^{144}$ MNL HBML VI. 127/111. 4. k. 126. és PJFN 27.
} 
Tukaszilágy, ${ }^{146}$ 1965: Szilágy, ${ }^{147}$ 1968: Szilágyasi rét, $-r e,{ }^{148}$ 1970: Szilágyasi-rét, ${ }^{149}$ 2013: Szilágy Szilágy-part ～Szílágy Szilágy-legelő Szilágyi-legelö Szilágyasi-rét.

Parlag-Tuka hátulja 'Tuka leghátsó részén, a külterület nyugati csücskében, a Selypes mellett elterülö földterület' 1968: Pallaktábla, -ra ${ }^{150}$ 1970: Pallag-tábla, ${ }^{151}$ 2013: Parlag-tábla $\sim$ Pallag-tábla $\sim$ Parlag $\sim$ Pallag Parlag-Tuka hátulja.

A fenti nevekben a Tuka névelem egy-egy régebb óta létező helynévhez utólag járult hozzá. Más nevekben viszont már a névadáskor közvetlenül is megjelenhetett.

Tuka-tanya 'egykori tanya Tukában' 1945: Tuka-tanya, ${ }^{152}$ 1945: Tuka tanya, ${ }^{153}$ 1946: Tuka tanya, ${ }^{154}$ 1947: Tuka tanya. ${ }^{155}$

Tukai út 'Tukára vezetô út' 2013: Tukai út.

Tuka-fok 'a külterület délnyugati részén, mélyenfekvő vizenyős rét, legelö Tukában' 1965: Tukafok, ${ }^{156}$ 1968: Tukafok, -ba ${ }^{157}$ 1970: Tuka-fok. ${ }^{158}$

Tuka-haszaj 'Tiszacsege felé tartó egykori patak' 1965: Tukahaszaj. ${ }^{159}$

Tuka hátulja Tuka háta 'a külterület délnyugati csücskében fekvő szántó' 1968: Tukahátújja, ${ }^{160}$ 1970: Tuka hátujja ${ }^{161}$ 2013: Tuka hátulja Tuka háta.

Tukai-háromszög 'a külterület nyugati csücskében, Tukában, a Tukai-tó elött található földterület' 2013: Tukai-háromszög.

Tukai-tó 'a határ nyugati részén, Tukában fekvő tó' 2013: Tukai-tó.

Kis-Tuka-tó 'egykori tó a mai Tukai-tó környékén' 1864: kis tuka tó. ${ }^{162}$

Nagy-Tuka-tó 'egykori tó a mai Tukai-tó környékén' 1864: Nagy tuka tó. ${ }^{163}$

Tukai-erdő 'Tuka belterületétől északnyugara fekvő erdő' 2013: Tukai-erdő Király-tói-erdö.

Kis-Tuka 'egykori tanya Tukában' 1965: Kistuka. ${ }^{164}$

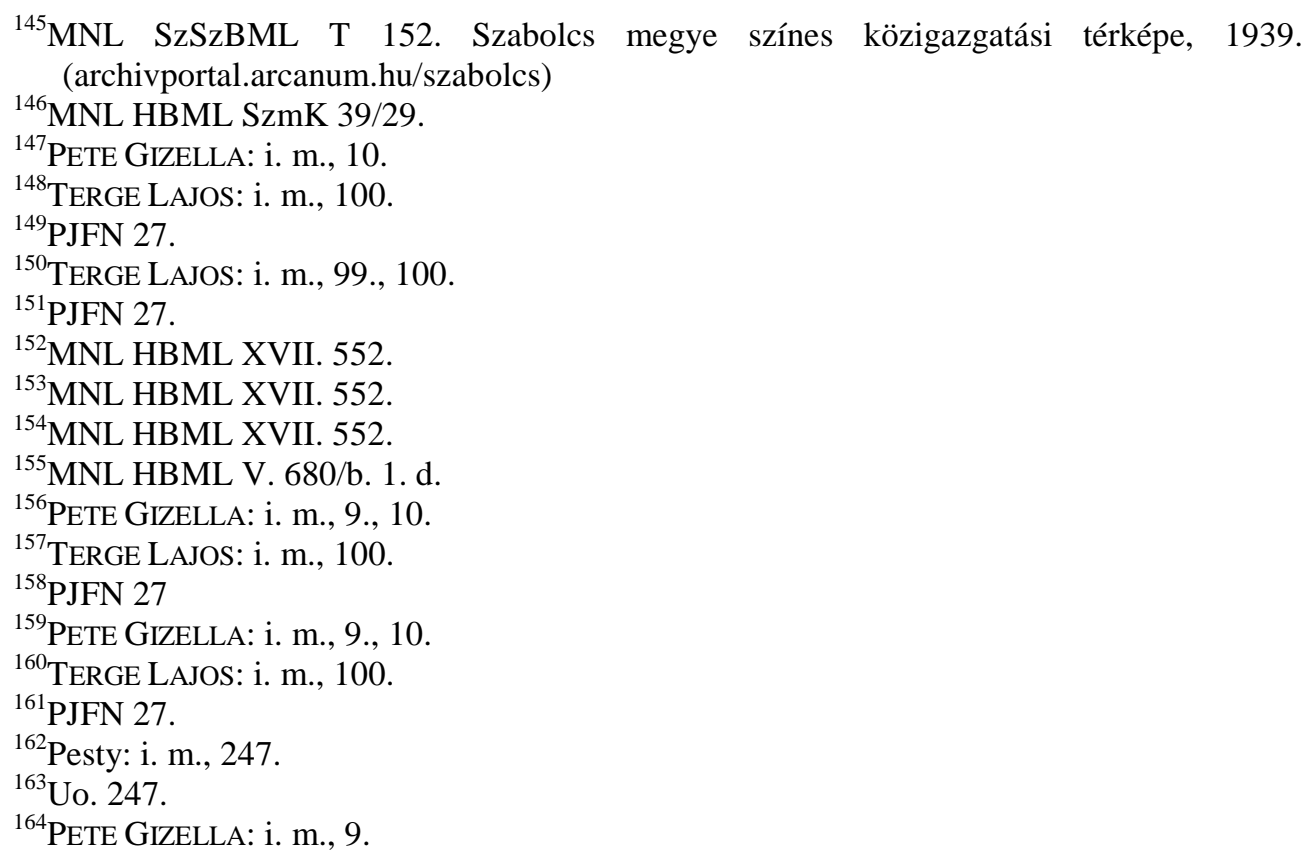




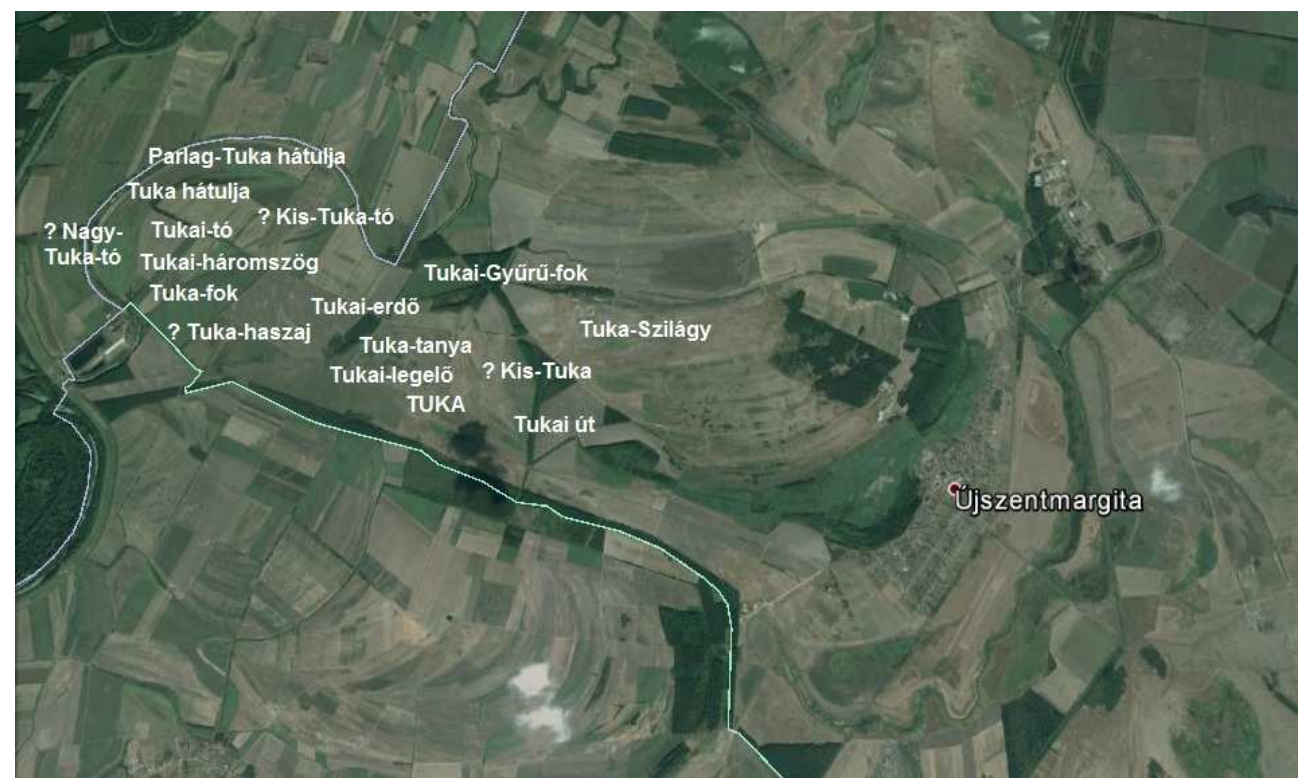

4. ábra: Tuka névbokra.

4. Görbeháza település neve az eddig áttekintett adatoktól eltérően nem középkori elpusztult településre utal. Polgár anyaközség területén a 19. század második felétől egyre több gazdasági központ alakult, melyek külterületi lakott helyek is voltak. Míg 1810-ben csak Szentmargitán, Borockáson és Tikoson voltak uradalmi központok, addig a kiegyezés előtti időben már harmincnégy külterületi lakott helyet találunk. ${ }^{165}$ Az 1910-es népszámlálás adatai között már uradalmi központként szerepel Görbeházpuszta, a későbbi Görbeháza névadója. ${ }^{166}$

Legnevezetesebb épülete egy L-alakú csárda volt, melyet szokatlan alaprajzi elrendezése miatt Görbe-csárdá-nak, Görbe-ház-nak neveztek (a jelenkori gyüjtésben említik ezt a csárdát, de történeti forrásokban nem találtam rá adatot). A szokatlan elrendezésű csárda vált az uradalmi gazdasági központ, majd pedig a telepesközség nevévé. ${ }^{167}$ A következő adatsorból látható, hogy a Görbeház Görbeháza alakok párhuzamosan voltak használatosak, a név tehát a -puszta jelző elhagyásával, grammatikai megformálással keletkezett: ${ }^{168}$ 1916: Görbeháza, ${ }^{169}$ 1943: Görbeházpuszta, ${ }^{170}$ 1945: Görbeház telepesközség, ${ }^{171}$ 1946: Görbeház, ${ }^{172}$

${ }^{165}$ NYAKAS MiKLÓS: i. m., 203.

${ }^{166}$ Uo. 203-204.

${ }^{167}$ Uo. 219.

${ }^{168}$ A településnevekben gyakran pusztán annyi változás történik, hogy módosítják a helytelennek tartott névszerkezetet, például ház $\square$ háza, falu $\square$ falva, föld $\square$ földe, ehhez lásd MEZÖ ANDRÁs: A magyar hivatalos helységnévadás. Bp., 1982. Az ilyen változásokban a helynévi minták analógiás hatásával kell elsősorban számolnunk. Érvényes ez az élőbeszéd nyelvhasználatára és a hivatalos névadásra egyaránt.

${ }^{169}$ MNL HBML SzmK 39/16., 17.

${ }^{170}$ MNL SzSzBML T 584. 
1945-47: Görbeháza község, ${ }^{173}$ 1959: Görbeház, ${ }^{174}$ 1959: Görbeháza, ${ }^{175} 1945$ : Görbe ház Görbeház Görbe háza. ${ }^{176}$

Németh Péter négy középkori falvat lokalizál a mai Görbeháza területére: Bagota, Bágy, Fövenyes és Úrkuta helységeket. Bag, Bagszeg és Bágy települések ahogy korábban arról szó esett - Németh Péter szerint Újszentmargita és Görbeháza területére lokalizálhatók. A nevek hasonlósága gondot okozhat az egyes megnevezések adatsorának felállításában, s mivel én Németh adatait felülvizsgálva némileg más adatsort állítottam össze ezekkel a falvakkal kapcsolatban, így ezeket most együtt tárgyalom.

Németh Péter Újszentmargita területére lokalizálja Bag Bagszeg települést. Az ő adatait felülvizsgálva és kiegészítve Bag falut nem azonosítom Bagszeggel (Bágyszeggel), hanem a következö adatokat vélem idetartozónak: 1259: Boog poss., ${ }^{177}$ 1337/1338: p. Boog, ${ }^{178}$ 1338: p. Boog, ${ }^{179}$ 1339: p. Moogh (recte: Boogh), ${ }^{180}$ 1347: p. Boog. ${ }^{181}$ Bag falváról mindössze annyit tudunk, hogy igen korán, már a 14. században elpusztult, s nem is épült újjá, későbbi adatai nincsenek. Újszentmargita határában fekhetett, de pontos helyéről nincsenek információk. Ma egyetlen név sem őrzi emlékét a falu határnevei között, így lokalizálását a későbbi-mai névanyag sem segíti. A Bag helynév puszta személynévből keletkezett magyar névadással; vö. 1138/1329: Bogu személynév, az alapjául szolgáló személynévhez lásd talán szorb R. Bog szn., cseh R. Boh szn ; le. R. Bog szn., és vö. ősszláv *bogъ 'isten'. ${ }^{182}$

A Németh Péter által Bagszegnek olvasott 1261/1271: item Bagzeg prope Hortubagwyze $^{183}$ adat valójában Bágyszeget jelölheti, mely nagy valószínűséggel egy Bágy nevü patak szegletében fekvő hely, esetleg település volt, mely igen korán elpusztulhatott. Polgár, Görbeháza, Folyás és Újszentmargita határában ma számos bágy lexémát tartalmazó név adatolható. A történeti adatok között Bagy morast, ${ }^{184}$ Lacus Bagy, ${ }^{185}$ Bágy folyam, ${ }^{186}$ szerepel. A mai élönyelvi adatok elszórtan, mintegy 30 km hosszan, észak-dél irányban szétterülve ábrázolhatók - tehát nem egy

\footnotetext{
${ }^{171}$ MNL HBML XVII. 552. 1. d.

${ }^{172}$ MNL HBML XVII. 552. 1. d.

${ }^{173}$ MNL HBML XVII. 564. 1. d. Az Újtikosi Földigénylő Bizottság iratai 1945-1947.

${ }^{174}$ MNL HBML XXIII. 9/c. 10. d. Földrendezési iratok: Görbeháza: 1959, 1961, 1963.

${ }^{175}$ MNL HBML XXIII. 9/c. 32. d.

${ }^{176}$ MNL HBML XVII. 525. 1. d. A görbeházai földigénylő bizottság iratai 1945-1947.

${ }^{177}$ Fejér György: Codex Diplomaticus II. Magyarország középkori digitális okmánytára 1.0. DVD-ROM. 2005. (a továbbiakban F.) IV/2: 522

${ }^{178}$ Anjou-kori Oklevéltár 21. Szerk.: BLAZOVICH LÁsZló, GÉCZI LAJOS Bp.-Szeged, 2005. (a továbbiakban AOkl) 518, 543, 627.

${ }^{179}$ DF 247883.

${ }^{180}$ AOkl 23. Szerk.: PITI FERENC. Bp.-Szeged, 1999. 74.

${ }^{181}$ Anjou-kori Okmánytár 1-6. Szerk.: NAGY IMRE. Bp., 1878-1884. (a továbbiakban A.) 5: 151; AOkl 31. Szerk.: SEBÖK FERENC. Bp.-Szeged, 2007. 1048.

${ }^{182}$ FNESz I. 135.

${ }^{183}$ DHA I: 60.

${ }^{184}$ EKFT.

${ }^{185}$ Lipszky: Mappa.

${ }^{186}$ Pesty: i. m., 309.
} 
középkori falura utalnak. A történeti adatok alátámasztják, hogy vizenyős, mocsaras terület volt itt egykor, ahol nagy valószínüséggel keresztuilhaladt egy Bágy nevü vízfolyás. Bágy vízfolyás létére utalhat még maga Bágyszeg neve is, ahogy már fentebb is említettem. ${ }^{187}$ Bágy történeti adatai közé sorolható esetleg a Csánki által Bágy-nak olvasott 1429: Baag ${ }^{188}$ is. Sajnos egyéb történeti adatok híján azonban Bágy település státusza sem biztos, ahogyan pontos helye is ismeretlen. Ha létezett egykor Bágy település, az nagy valószínüséggel a mellette folyó Bágy patakról kapta a nevét, de az is lehet, hogy Bágy patak mellett csupán egy földterület viselte a Bágyszeg nevet.

Németh a görbeházi Bágy adatai közé sorolja a következöket: 1219/1550: villanis de Bagya, ${ }^{189}$ v. Baga. ${ }^{190}$ E nevek olvasata azonban sokkal inkább Bágya ${ }^{191}$ lehet. Ennek pontos helye azonbab ismeretlen: GYÖRFFY szerint Heves megyében Heves és Poroszló között, esetleg Sarud környékén fekhetett, ${ }^{192}$ de Németh Péter a szabolcsi elhelyezkedését feltételezi ${ }^{193}$ Németh Péter nyilvánvalóan azért lokalizálja Görbeháza területére, mert az itteni határban számos bágy lexémát tartalmazó név van. Ugyanakkor - ahogyan fentebb láttuk - ezek a nevek nemigen lehetnek kapcsolatban egy Bágya nevü egykori településsel, így lokalizálásában sem nyújthatnak segítséget, Németh Péter tehát tévesen azonosítja a Váradi Regestrum Bágya adatait Bágy adataival. A település a tatárjáráskor pusztult el ${ }^{194} \mathrm{~A}$ Bágya név egyébként valószínűleg egy ugyanilyen alakú régi személynévből eredeztethetö. ${ }^{195}$

Bagota középkori falu ma is külterületi lakott hely. Igen gazdagon adatolható: 1310/1313: p. Bagata, ${ }^{196}$ 1347>1352: p. Bagota, ${ }^{197}$ 1355/1357: p. Bakatha ${ }^{198}$ 1411: pr. Bagata ....in Saboch C-us, ${ }^{199}$ 1426: in loco venationis Bagotha, ${ }^{200}$ 1476/1477: pr. Bagotha, ${ }^{201}$ 1576: Bagota, ${ }^{202}$ 1577: Bagota, ${ }^{203}$ 1767: Nzetes Ujv. Szabó István Ur instátiájára a Bagota nevezetü Tér Mezőből a Hattyasig bizonyos ideig való

\footnotetext{
${ }^{187}$ Lásd még ehhez BÉRES JÚLIA: Adalékok a Hortobágy etimológiájához. Helynévtörténeti tanulmányok. 2014. 33-52. 36-42.

${ }^{188}$ CSÁNKI DEZSÖ: i. m., 510.

${ }^{189}$ VR. 74.§, 221-2.

${ }^{190}$ VR. 79. $\S, 224$.

${ }^{191}$ lásd BÉRES: i. m. 41.

${ }^{192}$ GYÖRFFY GYÖRGY: Az Árpád-kori Magyarország történeti földrajza IV. Bp., 1987. 68., majd az ő nyomán K. FÁBIÁN ILONA: A Váradi Regestrum helynevei. Adattár. Szeged, 1997. 27.

${ }^{193}$ NÉMETH a: 28.

${ }^{194}$ NÉMETH b: Bágy szócikk.

${ }^{195}$ FEHÉRTÓI KATALIN: Árpád-kori személynévtár. 1000-1301. Bp., 2004.

${ }^{196}$ NÉMETH a: 27.

${ }^{197}$ NÉMETH a: 27.

${ }^{198}$ NÉMETH a: 27.

${ }^{199}$ NÉMETH b: Bagota szócikk.

${ }^{200}$ NÉMETH b: Bagota szócikk.

${ }^{201}$ DL 17893., 24566.

${ }^{202}$ H. FEKETE PÉTER: Hajdúböszörmény helyneveinek adattára. Bp., 1959. 40.

${ }^{203}$ Uo. 40.
} 
Árendában 80 forintokig ki adatott, ${ }^{204}$ 1769: A Hortobágy Zugja és a Bagota kaszálásra az el maradt gyalog emberek holnapra ki küldettetnek, ${ }^{205}$ 1864: Pródból a Bagota nevü birtokrész tagositás esetére szántófölddé alakittassék, ${ }^{206}$ 1869-1887: Bagota, ${ }^{207}$ 1909: Bagota, ${ }^{208}$ 1909: Bagota, ${ }^{209}$ 1945: Bagota, ${ }^{210}$ 1945: Bagota, ${ }^{211}$ 1947: Bagota, ${ }^{212}$ 1947: Bagota, ${ }^{213}$ 1947: Bagota,$~^{214}$ 1947: Bagota ${ }^{215}$ 1948: Kisnyiregyháza, ${ }^{216}$ 1955-1960: Bagota, ${ }^{217}$ 1956: Bagota, ${ }^{218}$ 1959: Bagotapuszta, ${ }^{219}$ 1965: Kisnyiregyháza Bagota, ${ }^{220}$ 1968: Bagota, -ra, ${ }^{221}$ 1970: Bagota Bakota, ${ }^{222}$ 1974: Bagota Bakota, ${ }^{223}$ 2013: Bagota Bakota Új-Bagota Kisnyíregyháza. - amint látjuk, a 14. század elejétől folyamatosan adatolható, birtokként számos oklevélben előfordul. 1476-ban a Hunyadiak birtokai között találjuk a Szabolcs megyei Böszörmény mezővárost és tartozékait, köztük Bagota pusztát is. Puszta személynévből keletkezett magyar névadással, az alapjául szolgáló személynév szláv eredetü, vö. szb-hv. R. Boguta szn., cseh R. Bohuta szn., le. R. Boguta szn. 224

1859-ben már külterületi lakott helyként jegyzik Bagotát, ${ }^{225}$ az 1910-es népszámláláskor viszont már Nagybagota néven szerepel külterületi lakott hely neveként. ${ }^{226}$ 1945-töl 1974-ig a Polgár területén alakult Újszentmargitához tartozott, ekkor csatolták Görbeházához, itt ma is külterületi lakott hely. Az adatközlők elmondása szerint amit ma Bagota külterületi lakott helyként ismerünk, az Fövenyesből alakult 1945 előtt. Fövenyes ma is külterületi határrész Bagotától északra, illetve egykori középkori feltételezett település (lásd lentebb). Bagotát az adatközlők szerint egy ideig Kisnyíregyházá-nak nevezték, vélhetően az itt fekvő Nyíregyházi rész nevü földterület miatt. Bagota neve a középkorban elpusztult

\footnotetext{
${ }^{204}$ Uo. 41 .

${ }^{205}$ H. FEKETE PÉTER: i. m., 41.

${ }^{206}$ Uo. 41.

${ }^{207}$ HKFT.

${ }^{208}$ PJFN 26.

${ }^{209}$ MNL HBML VI. 127/111. 4. k. 112., 132-134., 141., 142., 148., 149.

${ }^{210}$ MNL HBML XVII. 552. 1. d.

${ }^{211}$ MNL HBML XVII. 552. 1. d.

${ }^{212}$ MNL HBML V. 680/b. 1. d.

${ }^{213}$ MNL HBML V. 629/b. 1. d.

${ }^{214}$ MNL HBML V. 629/b. 1. d. Görbeháza nagyközség iratai. Közigazgatási iratok. 1/1947.

${ }^{215}$ MNL HBML V. 680/b. 1. d.

${ }^{216}$ MNL HBML V. 663/b. 1. d.

${ }^{217}$ MNL HBML XXX. 334/d. A görbeházai mezőgazdasági termelöszövetkezetek iratgyüjteménye 1949-1965. 1. d. Termelési ügyek 1955-1960.

${ }^{218}$ MNL HBML XXIII. 9/c. 32. d.

${ }^{219}$ MNL HBML XXIII. 9/c. 32. d.

${ }^{220}$ Pete Gizella: i. m., 6.

${ }^{221}$ TERGE LAJOS: i. m., 92.

${ }^{222}$ PJFN 26.

${ }^{223}$ BENCSIK JÁNOS: i. m., 231.

${ }^{224}$ FNESz. Bagota.

${ }^{225}$ BENCSIK JÁNOS: i. m., 231.

${ }^{226}$ Nyakas Miklós: i. m., 203-204.
} 
Bagota falu nevét viszi tovább. E kis falu pontos lokalizációjáról azonban nincs tudomásom. Németh Péter Görbeháza határába helyezi, Bagota lexémát tartalmazó nevek ma azonban nemcsak Görbeháza, hanem Hajdúböszörmény határában is nagy számban előfordulnak (a görbeházi határ mellett). Bagota névbokrát megvizsgálva véleményem szerint tehát az egykori falu a két település határán fekhetett. Hajdúböszörményben a külterületen legelőrészek, míg Görbeházán külterületi lakott hely neveként él tovább.

Bagota névbokrát eszerint érdemes a böszörményi és a görbeházi határban is megvizsgálni, hiszen mindkét település határnevei között gazdagon adatolható. Előtagként - $i$ képzős alakban a leggyakoribb, de jelzővel kiegészült alakja is gyakran előfordul.

Bagota nevek Görbeházán:

Bagota 'a belterülettől délre fekvő külterületi lakott hely' 1869-1887: Bagota, ${ }^{227}$ 1900: Bagota, ${ }^{228}$ 1909: Nyiregyházi rész, ${ }^{229}$ 1909: Nyiregyházirész, ${ }^{230}$ 1909: Nyíregyházi rész, ${ }^{231}$ 1909: Nyiregyházi rész, ${ }^{232}$ 1916: Nyiregyházi rész, ${ }^{233}$ 1945: Nyiregyházi rész, ${ }^{234}$ 1959: Bagota Bogota, ${ }^{235}$ 1966: Nyiregyházi rész, ${ }^{236}$ 1966: Nyiregyházirész. ${ }^{237}$

Bagotasi-legelö 'a mai Bagotán fekvő legelő' 2013: Bagotasi-legelö.

Bagotasi út 'a 35-ös főút felől Bagotára vezető út' 2013: Bagotasi út Bakotasi út $\sim$ Kövesút $\sim$ Makadámút.

Bagotasi-erdő 'a mai Bagota külterületi a lakott helytől északra fekvő erdő' 1968: Bagotasi erdő Karácsonyfás erdő, ${ }^{238}$ 1970: Bagotasi-erdő Bakotasi-erdő Fenyös-erdő Karácsonyfás-erdö, ${ }^{239}$ 2013: Bagotasi-erdő Karácsonyfás-erdö.

Nagy-Bagota 'a Lipcsei-háttól délre, a Fövenyes-háttól keletre, a hajdúböszörményi határ mellett található dülő' 1858: Nagy Bagota, ${ }^{240}$ 1909: Nagybagota, ${ }^{241}$ 1909: Nagybagota, ${ }^{242}$ 1909: Nagybagota, ${ }^{243}$ 1916: Nagybagota, ${ }^{244}$

${ }^{227}$ HKFT.

${ }^{228}$ MNL SzSzBML T 525.

${ }^{229}$ MNL HBML VI. 127/111. 7. k.

${ }^{230}$ MNL HBML VI. 127/III. 4. k. 102.

${ }^{231}$ MNL HBML VI. 127/11l. 4. k. 122.

${ }^{232}$ MNL HBML VI. 127/11l. 4. k. 93., 94., 112., 113., 123., 132-134.

${ }^{233}$ MNL HBML SzmK 32/1-33. Görbeháza (Szabolcs megye). A létesülendő telepes község határának térképe. Bp., 1916. 25., 28., 30., 34.

${ }^{234}$ MNL HBML XVII. 552. 1. d.

${ }^{235}$ MNL HBML XXIII. 9/c. 32. d.

${ }^{236}$ MNL HBML SzmK. 33/1-38. Görbeháza (Szabolcs megye). A község térképe. A felmérése 1916-ban készült, felújítási éve 1964. Az anyag 1930-1966 évi. Az eredeti sorrend csak az 1966 évieknél állapítható meg. Bp., 1966. 3, 7.

${ }^{237}$ MNL HBML SzmK 33/8.

${ }^{238}$ TERGE LAJOS: i. m., 92, 93.

${ }^{239}$ PJFN 26.

${ }^{240}$ MKFT.

${ }^{241}$ MNL HBML VI. 127/111. 7. k.

${ }^{242}$ PJFN 26. 
1916: Nagy bagota, ${ }^{245}$ 1934: Nagybagota, ${ }^{246}$ 1943: Nagybagota, ${ }^{247}$ 1945: Nagybagota, ${ }^{248}$ 1951-52: Nagybagota, ${ }^{249}$ 1955-1960: Nagy Bagota $\sim$ Nagybagota, ${ }^{250}$ 1956: Nagybagota, ${ }^{251}$ 1957, 1961, 1963, 1966: Nagybagota, ${ }^{252}$ 1959: Nagybagota, ${ }^{253}$ 1961: Nagybagota, ${ }^{254}$ 1963: Nagybagota, ${ }^{255}$ 1966: Nagy bagota, ${ }^{256}$ 1966: Nagybagota. ${ }^{257}$

Régi-Bagota 'a mai Bagotától északkeletre fekvő terület' 1959: Régi-Bagota. ${ }^{258}$

Nagy-Bagota-tanya 'egykori tanya Nagy-Bagotán, a böszörményi határszélen' 1869-1887: N. Bagota tn. ${ }^{259}$ 1900: Nagybagota, ${ }^{260}$ 1900: N.-Bagota tn. ${ }^{261}$ 1918: N.Bagota tn. ${ }^{262}$ 1924: N.-Bagota tn., ${ }^{263}$ 1927: N.-Bagota tn. ${ }^{264}$

Bagota-tanya 'a régi Bagota területén, a Hollós-ér és a Hortobágy-folyó között fekvő egykori tanya' 1858: Bagotay tanya, ${ }^{265}$ 1869-1887: Bagota tn., ${ }^{266}$ 1947: Bagota tanya, ${ }^{267}$ 1864: bagotai tanya hely, ${ }^{268}$ 1900: Bagota tn. ${ }^{269}$ 1909: Nyiregyházi tanya, ${ }^{270}$ 1945: Nyiregyházi tanya, ${ }^{271}$ 1946: Bagota tanya. ${ }^{272}$

Kis-Bagota-tanya 'a mai Bagota külterületi lakott hely területén lévő egykori tanya' 1869-1887: Kis Bagota tn., ${ }^{273}$ 1889: K. Bagota t., ${ }^{274}$ 1897: K. Bagota t. ${ }^{275}$

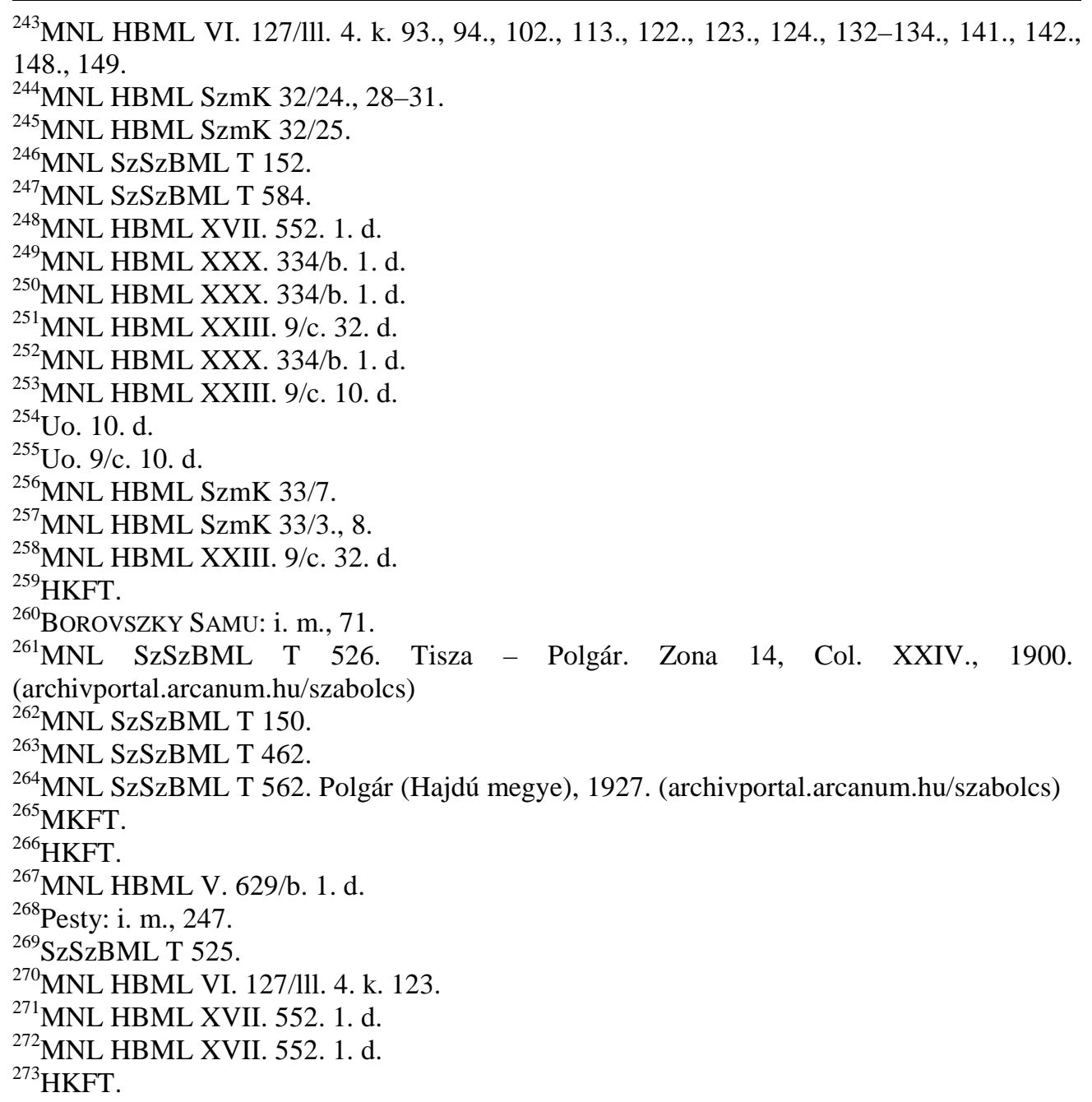


1900: Kisbagota, ${ }^{276}$ 1904: Kis-Bagota tanya, ${ }^{277}$ 1918: Kis-Bagota tn., ${ }^{278}$ 1924: KisBagota tn. ${ }^{279}$

Újszentmargitán:

Bagotasi út 'Bödönhát felől a Görbeháza határában fekvő Bagota felé tartó út, a külterület keleti részén' 2013: Bagotasi út Bakotasi út.

Bagota nevek Hajdúböszörményben. ${ }^{280}$

Bagota 'a határ nyugati szélén a Hortobágytól nyugatra fekvő puszta, legelö' 1959: Bagota Bakota, ${ }^{281}$ 1959: Bogota, ${ }^{282}$ 2011: Bagota.

Bagota-hát 'a Bagota emelkedett, magasabban fekvő része' 1894: Jelentés a Kövér Pál tanyájánál levő Kadarcs fenéktől a Bagota hátig terjedő lejtmérezésröl, ${ }^{283}$ 1959: Bagota-hát ${ }^{284}$ 2011: Bagota-hát.

Bagotai út 'Hajdúböszörményből a Bagotára vezető út, Pródot és Bagotát köti össze' 2011: Bagotai út.

Bagotai-csőszház 'Bagota-pusztán fekvő csőszház, ma tanya' é.n.: 2 drb a Bagota-háznál levő töréspontban, ${ }^{285}$ 1959: Bagota csőszház Bagota-ház, ${ }^{286}$ 2011: Bagotai-csőszház Csőszház.

Bagotai híd 'a Bagotai-csőszház közelében lévő híd a Hortobágyon' 2011: Bagotai híd.

Kis-Bagota 'Bagota közelében, a görbeházi határ mellett fekvő külterületi lakott hely, legelő, szántó' 1790: Kis Bakota, ${ }^{287}$ 1790: A Nádtü foka mellett Kis Bagotán a Hattyas oldalon, ${ }^{288}$ 1959: Kis-Bagota $\sim$ Kis-Bakota, ${ }^{289}$ 2011: Kis-Bagota $\sim$ KisNyíregyháza.

Kis-Bagota-hát 'Kis-Bagota magasabban fekvő része' 1861: Réten a Kis Bagota Háton, ${ }^{290}$ 1959: Kis-Bagotahát. ${ }^{291}$

\footnotetext{
${ }^{274}$ MNL SzSzBML T 108.

${ }^{275}$ MNL SzSzBML T 373.

${ }^{276}$ BOROVSZKY SAMU: i. m., 71.

${ }^{278}$ MNL SzSzBML T 150.

${ }^{279}$ MNL SzSzBML T 462. Debrecen, 2015. 99-252.

${ }^{281}$ H. FEKETE PÉTER: i. m. 40.

${ }^{282}$ Uo. 46.

${ }^{283}$ Uo. 41.

${ }^{284}$ Uo. 41.

${ }^{285}$ H. FEKETE PÉTER: i. m. 41.

${ }^{286}$ Uo. 41

${ }^{287}$ Uo. 41 .

${ }^{288}$ Uo. 41.

${ }^{289}$ H. FEKETE PÉTER: i. m., 74.

${ }^{290}$ Uo. 41.

${ }^{291}$ Uo. 75.
}

${ }^{277}$ MNL SzSzBML T 110., KoguTowicz 44.

${ }^{280}$ A 2011-es évszám E. Nagy Katalin hajdúböszörményi gyűjtésének évét jelöli. Közreadja KATONA CSILlA-E. NAGY KATALIN: Hajdúböszörmény helynevei. In: A Hajdúböszörményi és a Hajdúhadházi járás helynevei. Hajdú-Bihar helynevei 1. Szerkesztette: BÁBA BARBARA. 
Nagy-Bagota 'Bagota Tirimpótól a Hattyasig tartó része' 1750: ez vagyon a Hattyas parton Nagy-Bagota vígin, ${ }^{292}$ 1779: a Hattyastól a Hármasig a Nagy Bagotát kaszálják, ${ }^{293}$ 1788: A Nagy Bagota szántásra tiltatik, ${ }^{294}$ 1848: A Nagy Bagotai kaszáló el osztására ki rendelt küldöttek jelentik, ${ }^{295}$ 1857: Nagy-Bagota, ${ }^{296}$ 1959: Nagybagota, ${ }^{297}$ 1959: Nagy-Bagota, ${ }^{298}$ 2011: Nagy-Bagota.

Nagy-Bagota farka 'feltehetően a Nagy-Bagota határrész elkeskenyedő része' 1764: 11 határ ez vagyon a Nagy-Bagota farkon a Hattyas ér Partyán, ${ }^{299}$ 1811: a 12ik a Nagy-Bagota farkán a hattyas parton, ${ }^{300}$ 1959: Nagy-Bagota farka NagyBagota-farok. ${ }^{301}$

Nagy-Bagota-hát 'a Nagy-Bagota magasabban fekvő, kevésbé vízjárta része' 1789: A Nagy Bagota Háton 15 köböl alá való föld, ${ }^{302}$ 1959: Nagybagotahát. ${ }^{303}$

Új-Bagota 'Bagota újabb része, melyet az I. világháboú után kapott a város az egri káptalan legelőjéből' 1959: Újbagota, ${ }^{304} 2011$ : Új-Bagota.

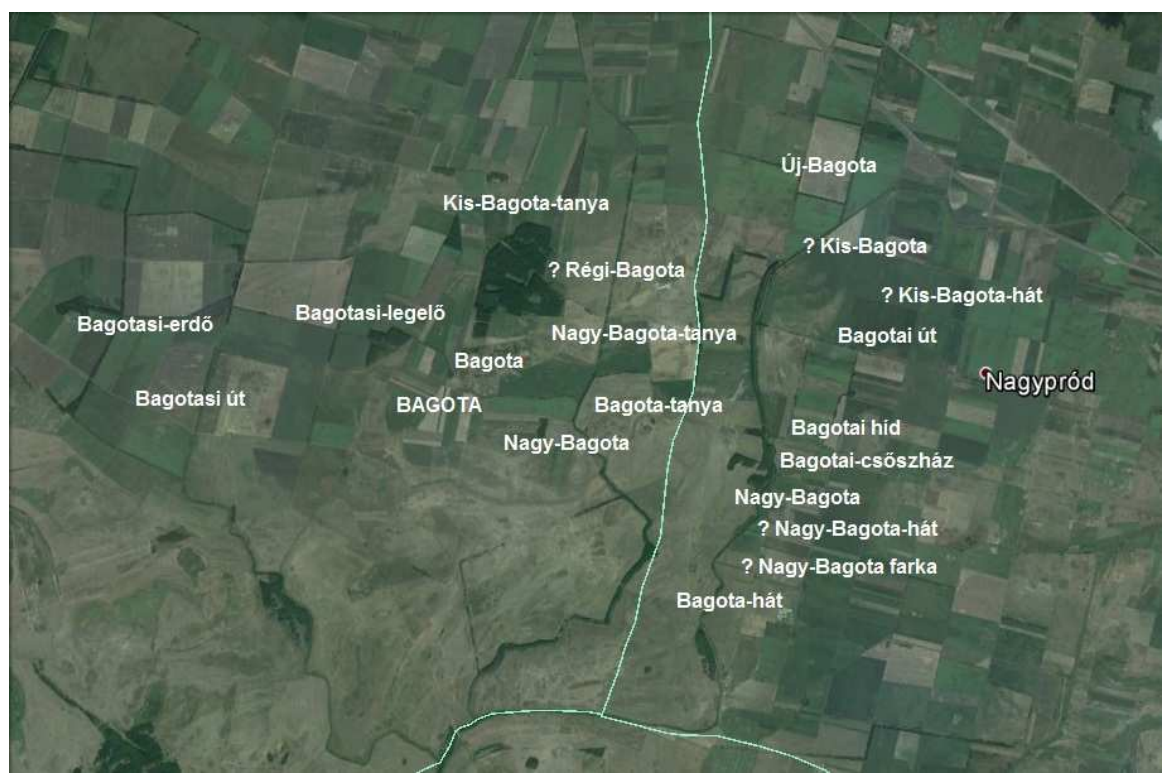

5. ábra: Bagota névbokra.

${ }^{292}$ Uo. 40.

${ }^{293}$ H. FEKETE PÉTER: i. m., 40.

${ }^{294}$ Uo. 41.

${ }^{295}$ Uo. 41.

${ }^{296}$ Uo. 86.

${ }^{297}$ H. FEKETE PÉTER: i. m. 86.

${ }^{298}$ Uo. 40.

${ }^{299}$ Uo. 40.

${ }^{300}$ Uo. 40.

${ }^{301}$ H. FEKETE PÉTER: i. m. 40.

${ }^{302}$ Uo. 41.

${ }^{303}$ Uo. 86.

${ }^{304}$ Uo. 113. 
A következő település, melyet Görbeháza területére lokalizálhatunk, Fövenyes 1476/1477: pr. Fewenyes, ${ }^{305}$ 1476/1477: pr. Fevenyes, ${ }^{306}$ 1851: Fövenyes. ${ }^{307}$ 1476ban a Hunyadiak birtokai között találjuk a Szabolcs megyei Böszörmény mezővárost és tartozékait, köztük Fövenyes pusztát is. ${ }^{308}$ A középkori Fövenyes település elhelyezkedésére vonatkozóan azonban semmilyen információval nem rendelkezünk, a mai Fövenyes határrész miatt helyezheti Németh Péter is Görbeháza határába. Az adatolás alapján birtokról van szó, amelyen egyáltalán nem biztos, hogy valaha laktak, azaz település státuszban volt. 1851-ben puszta Szabolcs vármegyében. ${ }^{309} 1885$-ben már lakott helyként jegyzik Fövenyes-hát-at, ${ }^{310}$ innentől gazdagon adatolható: 1900: Fövenyeshát, ${ }^{311}$ 1909: Fövenyeshát, ${ }^{312}$ 1909: Fövenyéshát, ${ }^{313}$ 1909: Fövenyes-hát Fövenyës-hát, ${ }^{314}$ 1916: Fövenyeshát ${ }^{315} 1916$ : Fövényeshát ${ }^{316}$ 1916: Fövényeshát, ${ }^{317}$ 1916: Fövenyeshát, ${ }^{318}$ 1916: Fövényes, ${ }^{319}$ 1927: Fövenyeshát, ${ }^{320}$ 1934: Fövényeshát, ${ }^{321}$ 1943: Fövenyes hát Fövenyeshát, ${ }^{322}$ 1945: Fövenyes, ${ }^{323}$ 1945: Fövenyeshát, ${ }^{324}$ 1945: Fövényeshát Fövenyeshát Fövényeshát, ${ }^{325}$ 1946: Fövenyeshát puszta, ${ }^{326}$ 1947: Fövenyes, ${ }^{327}$

\footnotetext{
${ }^{305}$ DL 17893., 24566.

${ }^{306}$ DL 24566.

${ }^{307}$ FÉNYES ELEK: Magyarország Geographiai szótára, mellyben minden város, falu és puszta, betürendben körülményesen leiratik II. Pest, 1851. 23.

${ }^{308}$ CSÁNKI DEZSÖ: i. m., 633., NÉMETH a: 76., ZOLTAI LAJOS: Eltünt falvak és elfelejtett régi helynevek Hajduvármegye mai területén. Debreceni Képes Kalendárium, 1926. 104-113. is csak ennyit mond.

${ }^{309}$ FÉNYES ELEK: i. m., 23.

${ }^{310}$ BENCSIK LAJOS: i. m., 236.

${ }^{311}$ BOROVSZKY SAMU: i. m., 71.

${ }^{312}$ MNL HBML VI. 127/11l. 4. k. 91-94., 100-102., 111-113., 121-123., 131-132., 139142., 146-147., uo. VI. 127/111. 7. k.

${ }^{313}$ Uo. VI. 127/III. 4. k. 91., 112.

${ }^{314}$ PJFN 24.

${ }^{315}$ MNL HBML SzmK 39/49., 51., 5., 25., 26., 24., 6., 34., 35., 14., 42-45., uo. SzmK. 32/22-24., 26., 28-31., uo. SzmK 38/1-66. = Polgár (Szabolcs megye). A település határtérképe. Bp. 1916. 58, 64.

${ }^{316}$ MNL HBML SzmK 39/15.

${ }^{317}$ Uo. SzmK 38/66.

${ }^{318}$ Uo. SzmK 39/50. és 32/27.

${ }^{319}$ MNL HBML SzmK 39/16.

${ }^{320}$ MNL SzSzBML T 562.

${ }^{321}$ Uo. T 152.

${ }^{322}$ Uo. T 584.

${ }^{323}$ MNL HBML XVII. 552. 1. d.

${ }^{324}$ Uo. XVII. 552. 1. d.

${ }^{325}$ Uo. XVII. 552. 1. d.

${ }^{326}$ Uo. XVII. 525. 1. d.

${ }^{327}$ MNL HBML V. 629/b. 1. d. és uo. V. 680/b. 1. d.
} 
1947: Fövenyeshát, ${ }^{328}$ 1948: Fövenyeshát, ${ }^{329}$ 1948: Fövényes hát, ${ }^{330}$ 1951-52: Fövenyeshát, ${ }^{331}$ 1955-1960: fövenyeshát, ${ }^{332}$ 1955-1960: Fövenyes, ${ }^{333}$ 1956: Fövenyeshát, ${ }^{334}$ 1957, 1961, 1963, 1966: Fövenyeshát, ${ }^{335}$ 1959: Fövenyes hát, ${ }^{336}$ 1959: Fövenyeshát, ${ }^{337}$ 1959: fövenyes, ${ }^{338}$ 1966: Fövenyeshát, ${ }^{339}$ 1966: Fövényeshát, ${ }^{340}$ 1968: Fövenyës Füvenyeshát ${ }^{341}$ 1970: Fövenyës Fövenyëshát, ${ }^{342}$ 1974: Fövenyeshát ${ }^{343}$ 2013: Fövenyes $\sim$ Fövenyes-hát $\sim$ Fövenyesi-dülö. Ma Bagotától északra helyezkedik el, az adatközlők szinonim értelemben használták a Fövenyes és Fövenyes-hát kifejezéseket. Ma már nem lakott terület, dűlő örzi csupán a nevét. A helynév a magyar föveny 'homok' fn. -s képzős származékából keletkezett. ${ }^{344}$

Fövenyes neve csupán a közvetlen környezetében található négy objektum nevében örződött meg, az objektumok elötagja három esetben a Fövenyes $-i$ képzős alakja:

Fövenyesi-árok 'Fövenyesen keresztülfolyó patak' 1968: Fövenyesi árok, ${ }^{345}$ 1970: Fövenyësi-árok, ${ }^{346}$ 2013: Fövenyesi-árok.

Fövenyesi út 'a Vitéz-telektől délre, a Fábián-árok és a Kántor-árok találkozásától induló, Bagota felé vezető földút' 2013: Fövenyesi út.

Fövenyesháti-tanya 'a Kis-Bagota-tanyától északra fekvő egykori tanya' 1900: Fövényesháti tn. (Kis-Bagota tn.), ${ }^{347}$ 1916: Fövényeshát tanya, ${ }^{348}$ 1945: Fövényeshát tanya, ${ }^{349}$ 1946: Fövenyes tanya. ${ }^{350}$

Fövenyes-tanya 'egykori tanya Fövenyesen' 1946: Fövenyes tanya. ${ }^{351}$

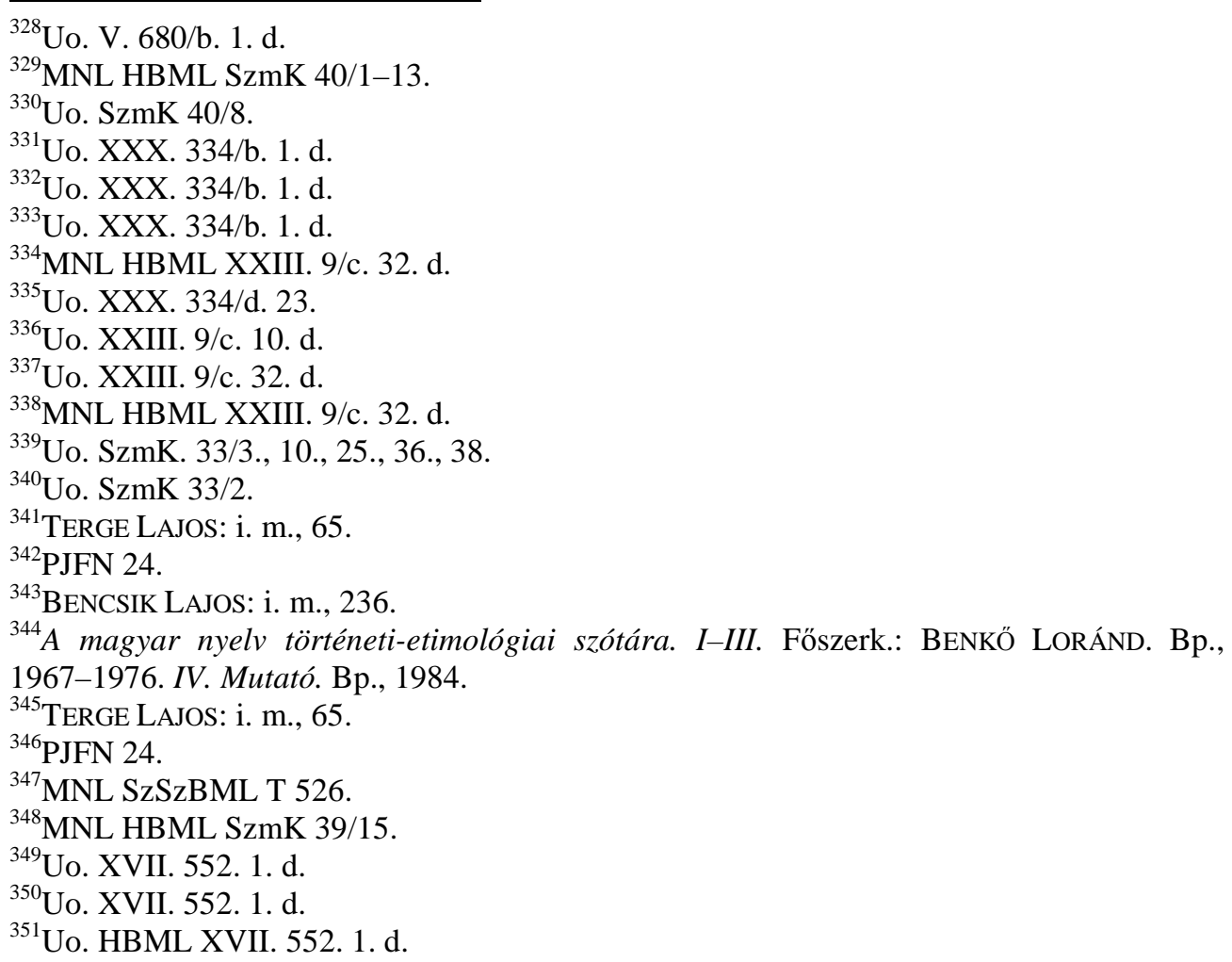




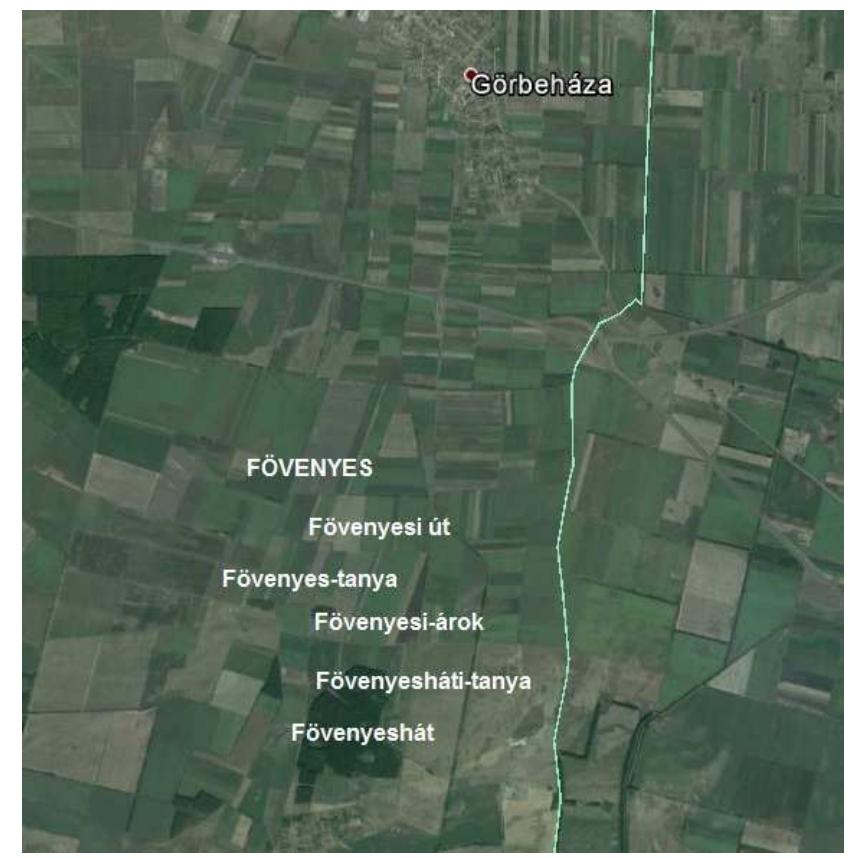

6. ábra: Fövenyes névbokra.

Végül összefoglalásként nézzük, hogyan helyezkedhettek el az eddig említett elpusztult települések egymáshoz viszonyítva a vizsgált területen!

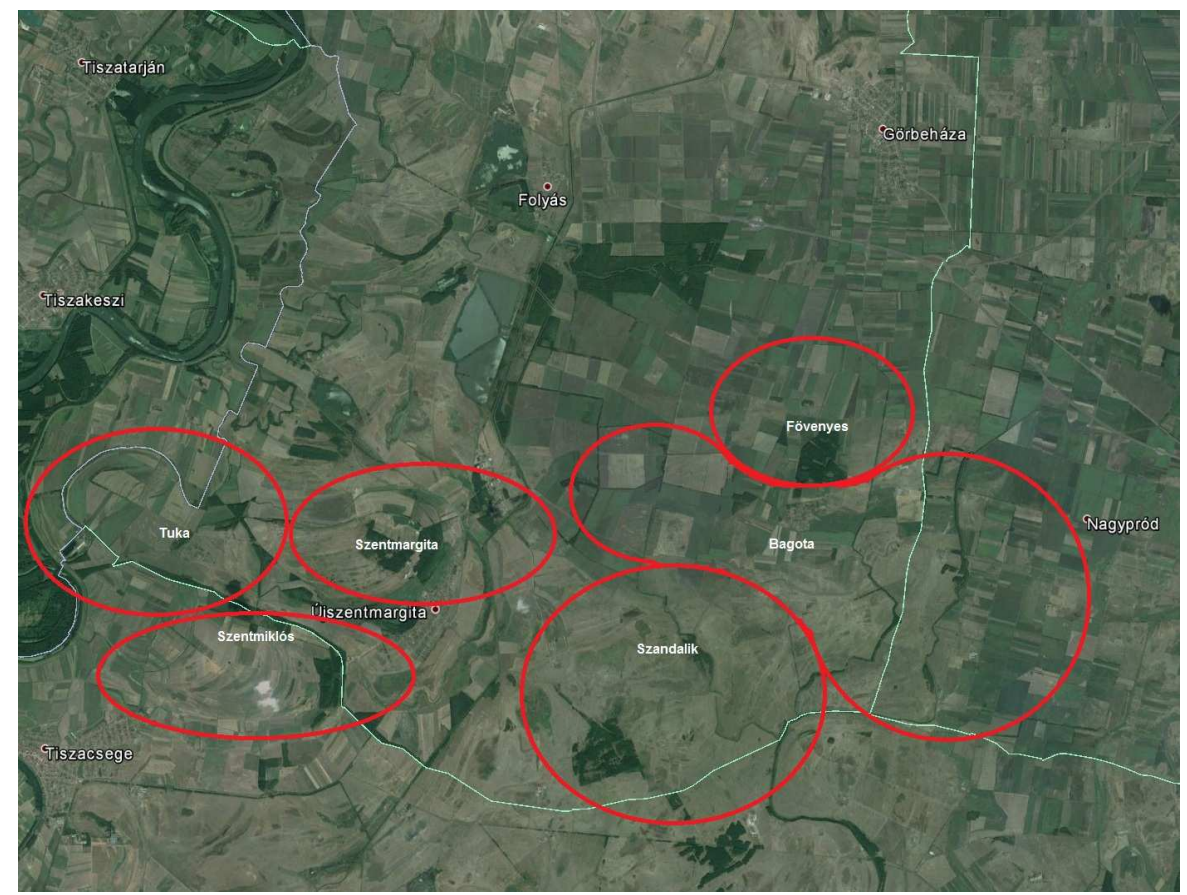

7. ábra: Az elpusztult települések feltételezett fekvése. 